\title{
Effect of maternal nutrition and days of gestation on pituitary gland and gonadal gene expression in cattle
}

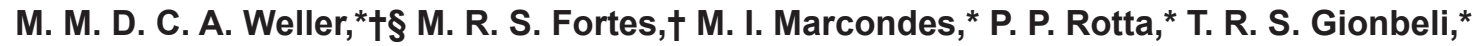 \\ S. C. Valadares Filho, ${ }^{*}$ M. M. Campos, $\ddagger$ F. F. Silva, ${ }^{*}$ W. Silva, ${ }^{*}$ S. Moore, $§$ and S. E. F. Guimarães ${ }^{* 1}$ \\ *Animal Science Department, Universidade Federal de Viçosa, 36570-000, Viçosa, MG, Brazil \\ †School of Chemistry and Molecular Biosciences, the University of Queensland, Brisbane, 4067 Australia \\ †Embrapa Gado de Leite, Juiz de Fora, Brazil 36038-330 \\ $\S$ Queensland Alliance for Agriculture and Food Innovation, Center for Animal Science, the University of Queensland, Brisbane, 4062 Australia
}

\begin{abstract}
This study investigated effects of maternal overnutrition on gonadal development and pituitary-gonadal gene expression in cattle fetuses at mid- and lategestation. Twenty-seven multiparous dry cows were fed either high (ad libitum, H) or moderate (M) intake of the same diet. Twelve cows from $\mathrm{H}(\mathrm{n}=6)$ and $M(n=6)$ intake carrying females fetuses were euthanized at 199 and $268 \mathrm{~d}$ of gestation (DG; $\mathrm{n}=3$ for $\mathrm{H}$ or $\mathrm{M}$ on each $\mathrm{DG})$. Fifteen cows from $\mathrm{H}$ ( $\mathrm{n}=$ $6)$ and $M$ intake $(n=9)$ carrying male fetuses were euthanized at 139, 199, and $241 \mathrm{DG}(\mathrm{n}=2$ for $\mathrm{H}$ and $\mathrm{n}=3$ for $\mathrm{M}$ on each DG). Fetal gonads and pituitary gland were sampled for gene expression and histological analyses. Sex-specific responses to maternal intake were observed. Primordial and total follicle numbers were lower in fetal ovaries from $\mathrm{H}$ than in $\mathrm{M}$ intake cows. These results were the reverse for preantral and antral follicles. Volumetric proportion and diameter of seminiferous cord were lower in fetal testis of $\mathrm{H}$ than $\mathrm{M}$ intake cows. The expression level of $F S H B$ was greater in pituitary gland of the female fetus from $\mathrm{H}$ compared with $\mathrm{M}$ intake cows, irrespective of DG, whereas $L H B$ gene expression did not differ. In males, $F S H B$ and $L H B$ gene expression levels were similar between maternal intake groups. Fetal ovarian expression of $P 450$ aromatase, StAR, BMPR2, TGFBR1, GDF9, FSHR, Bax, and $C A S P 3$ genes were higher in $\mathrm{H}$ than in $\mathrm{M}$ intake cows, irrespective of DG. Fetal testicular expression of StAR, HSD17B3, IGF1, IGF2, and IGF1R genes was higher in $\mathrm{M}$ than in $\mathrm{H}$ intake cows. The differences in gene expression for steroidogenesis, folliculogenesis, and apoptosis may explain the distinct pattern of follicular growth between offspring of $\mathrm{M}$ and $\mathrm{H}$ intake cows. By contrast, the lower volumetric proportion, diameter,
\end{abstract}

Received August 8, 2015.

Accepted December 3, 2015.

${ }^{1}$ Corresponding author: sfacioni@ufv.br and length of seminiferous cord may relate to decreased gene expression in fetal testis from $\mathrm{H}$ intake cows. In conclusion, maternal $\mathrm{H}$ intake seems to affect fetal ovarian follicular growth and number of follicles, which may affect the size of ovarian reserve in their offspring. In male fetus, maternal $\mathrm{H}$ intake seems to disturb testicular development and may have implications on sperm production. The underlying mechanism of differential gene expression and the effect on offspring reproductive potential should be the focus of further research, especially considering larger sample size, reducing the chance for type I errors.

Key words: bovine species, fetal development, overnutrition, real-time PCR, reproduction

\section{INTRODUCTION}

Maternal nutrition status has been considered as a major cause of developmental programming. The resultant changes in phenotypes can enhance susceptibility to diseases in adult offspring (Symonds and Budge, 2009; Williams et al., 2014) such as type 2 diabetes (Jones and Ozanne, 2009; Portha et al., 2011), hypertension (Ingelfinger and Nuyt, 2012), obesity (Parlee and Macdougald, 2014), and alterations in offspring reproductive function (Chadio and Kotsampasi, 2014; Chavatte-Palmer et al., 2014; Zambrano et al., 2014).

Many studies reported detrimental effects of maternal undernutrition on offspring reproductive development. In rats, female offspring of undernourished mothers had reduction in ovarian follicular number and mRNA levels of FSHR, GDF9, ER, and CYP17A1 genes (Bernal et al., 2010). In sheep, maternal undernutrition delayed follicular development (Rae et al., 2001), increased the expression of apoptotic genes in fetal ovary (Lea et al., 2006), and increased the expression of StAR in male sheep fetuses (Rae et al., 2002). Moreover, heifers born to nutritionally restricted dams had $60 \%$ reduction of mean antral follicular count during follicular waves (Mossa et al., 2009). In contrast, the effects of mater- 
nal overnutrition on offspring reproductive organs have been less studied. Early puberty has been reported in rodents and rabbit offspring with prolonged or persistent estrus (Sloboda et al., 2009; Connor et al., 2012; Léveillé et al., 2014) and reduction in the number of primordial and total follicles in sheep fetuses (Da Silva et al., 2003). In males, maternal high-fat diet resulted an increased testicular and sperm oxidative stress, leading to decrease of fertility in rats (Rodríguez-González et al., 2015). Moreover, Long et al. (2012) reported that maternal obesity altered hypothalamic-pituitaryadrenal function in rat offspring.

Considering these previous results, we hypothesized that maternal overnutrition during mid- and lategestation affects fetal pituitary-gonadal development. The objectives of this present study were to determine (1) whether maternal overnutrition alters gonadal germ cell development and (2) whether maternal overnutrition affects gonadal and pituitary gland gene expression in cattle fetuses at mid- and late-gestation. In this context, we examined fetal pituitary gonadotropin gene expression and gonadal expression of candidate genes. In female fetuses, we evaluated the expression pattern of key genes involved in ovarian folliculogenesis (ESR- $\alpha, F H S R$, BMPR2, GDF9, TGFBR1, and TGFB1), steroidogenesis (StAR and P450arom) and anti- or pro-apoptotic factors (Bax, Bcl2, and CASP3). In male fetuses, we evaluated the expression pattern of key genes involved in testis development and function (AR, LHCGR, IGF1, IGFR1, IGF2, StAR, and $H S D 1^{7}$ B 3$)$, as well as apoptotic factors (Bax, Bcl2, and CASP3).

\section{MATERIALS AND METHODS}

Management, handling, and euthanasia of animals were approved by the Institutional Animal welfare and Ethics/Protection commission (certificate number 47/2012) from the Universidade Federal de Viçosa, Brazil. This research is part of a larger project titled "Nutrient requirements of Holstein-Gyr pregnant dairy cattle."

\section{Experimental Design and Animal Management}

Unsuckled multiparous crossbreed (Holstein $\times$ Gyr) cows $(\mathrm{n}=62)$ had their estrus cycles synchronized for the experiment. Estrus synchronization protocol used a vaginal progesterone insert (CIDR, Zoetis, Florham Park, NJ) for $7 \mathrm{~d}$ and with a $\mathrm{PGF}_{2 \alpha}$ injection $(25 \mathrm{mg}$, Lutalyse, Zoetis) was administered at CIDR removal. Cows were monitored for estrus every $12 \mathrm{~h}$ and were artificially inseminated using semen from a single bull 12 $\mathrm{h}$ after the onset of estrus. On d 40 of gestation, cows were housed in $30 \mathrm{~m}^{2}$ individual pens, of which $8 \mathrm{~m}^{2}$ were covered with concrete flooring. Pens had individual feed bunks and an automatic water system. On d 55 of gestation, the pregnancy was verified, fetal sexing was performed by using transrectal ultrasound (Aloka 500 with a $5-\mathrm{MHz}$ linear probe Aloka, Wallingford, CT), and 27 pregnant cows were randomly selected from the 62 for this experiment. The nutritional regimens were provided from d 60 of gestation until cows achieved their previously designated days of gestation (DG), when they were euthanized for sampling.

Twenty-seven multiparous dry cows with an average initial BW of $480 \pm 10.1 \mathrm{~kg}$ and an age of $5 \pm 0.5$ yr were fed either high $(\mathbf{H}$, ad libitum) or moderate (M) intake of the same diet during their gestation. The moderate level was designed to meet $100 \%$ of requirements for maintenance, which was considered to be $1.15 \%$ of BW (DM basis) as reported by our research group before Rotta et al. (2014). Every 28 d, cows were weighed in the morning before feeding and after a 16 $\mathrm{h}$ fast to obtain the shrunk BW. The shrunk BW was estimated after collecting all of the feed in the feeders, $16 \mathrm{~h}$ before weighing, to standardize the BW. Feed intake was adjusted based on values of shrunk BW to maintain a moderate level throughout the entire gestation period. The high level was designed to meet $190 \%$ of requirements for maintenance as reported by our research group (Rotta et al., 2014). Cows fed ad libitum $(\mathrm{H})$ were considered obese in this current study; $\mathrm{H}$ cows had an ADG about 3.8 times greater than $\mathrm{M}$ intake cows. Also cows fed ad libitum had an increased rib fat thickness during gestation, whereas M intake cows had a constant amount of rib fat thickness (for details on weight and fat measurements, see Rotta et al., 2014). All cows were fed corn silage and concentrate-based diet at a ratio of 93:7 on a DM basis as a TMR twice daily, with $60 \%$ of the amount offered in the morning and $40 \%$ in the afternoon feeding (DM basis). All cows had ad libitum access to water. The composition of the experimental diet is presented in Supplemental Table S1 (http://dx.doi.org/10.3168/jds.2015-9673).

To evaluate the effects of different DG on pituitarygonadal developments of female and male fetuses, pregnant cows were euthanized at selected time points. Six cows from either $\mathrm{H}$ or $\mathrm{M}$ intake carrying female fetuses were randomly divided for euthanasia at 199 and $268 \mathrm{~d}$ of gestation. The 4 groups of treatments therefore comprised H-199DG, M-199DG, H-268DG, and M-268DG with 3 cows for each treatment. Six $\mathrm{H}$ and $9 \mathrm{M}$ intake cows carrying male fetuses were randomly divided for euthanasia at 139, 199, and 241 DG. The 6 groups of treatments thus comprised H-139DG, M-139DG, H199DG, M-199DG, H-241DG, and M-241DG with 2 cows from $\mathrm{H}$ and 3 cows from $\mathrm{M}$ intake for each DG. 
Time points set for euthanasia represent important windows of gonadal development in male and female fetuses. We evaluated the female fetuses at 199 and 268 DG to represent 2 stages of ovarian fetal development. The initial folliculogenesis and steroidogenesis occur at 130 to $140 \mathrm{DG}$, the greater wave of apoptosis occurs at 120 to $150 \mathrm{DG}$, and antral follicles are first seen in bovine fetal ovaries aged 230 DG (Erickson, 1966; Chavatte-Palmer et al., 2014). Thus, at 199 DG, initial folliculogenesis and apoptosis would have occurred, but no antral follicles would be present. We evaluated male fetuses at 139, 199, and 241 DG because the respective time points represent the mid- and late-stage of gestation where testicular architecture becomes more differentiated, the proliferation of pre-spermatogonia arrests at 200 DG (Wrobel, 2000), and from 210 to 285 DG the interstitium greatly expands, whereas the number of fetal Leydig cells are reduced (Abd-Elmaksoud, 2005). Therefore, we hypothesized that the maternal nutrition could affect these important events during ovarian and testicular development.

Euthanasia procedures were performed on the same calendar day for each DG. Feed was withheld overnight, but cows had ad libitum access to water. Cows were euthanized at the Universidade Federal de Viçosa by stunning with a captive bolt and subsequent exsanguination. The gravid uterus was sectioned at the cervix, and the fetuses were immediately removed and weighed. As soon as possible after euthanasia, the reproductive organs and pituitary gland of fetuses were removed and the reproductive organs weighed.

The left ovaries and testicles from the fetuses were promptly dissected, weighed, and immersion fixed in Bouin's solution for $24 \mathrm{~h}$ and then stocked in ethanol $70^{\circ} \mathrm{C}$. The right ovaries, testicles, and pituitary were immediately immersed in $10 \mathrm{~mL}$ of RNAholder (BioAgency, São Paulo, Brazil) to protect and conserve the expression profiles of these tissues. After $16 \mathrm{~h}$, the collected material were removed from RNAholder, drained, and stored in an ultra-freezer $\left(-80^{\circ} \mathrm{C}\right)$ until RNA extractions were carried out.

\section{Gonadal Histology}

Left ovaries and testis were sliced crosswise in 3-mmthick blocks, which were dehydrated in increasing concentrations of ethanol $\left(70,95\right.$, and $\left.100^{\circ} \mathrm{C}\right)$, cleared in xylene and embedded in paraffin wax. Paraffinembedded blocks were sectioned serially at 5 - $\mu$ m-thick slices and stained with hematoxylin-eosin for examination of germ cell development. An average of 30 gonadal sections was examined per fetus. After qualitative evaluation of the slides, images of stained ovarian sections were retrieved from a video camera linked to light microscope (EVOS XL Core Cell Imaging System, Life Technologies, Carlsbad, CA) at a magnification of $40 \times$ and these images were analyzed with ImageJ 1.48 software (National Institutes of Health, Bethesda, $\mathrm{MD})$. The width of the cortical layer was measured at $20 \times$ magnification.

Twenty randomly selected fields per section were examined in each fetal ovary. Ovarian structures were classified as primordial follicles (germ cells surrounded by flattened follicular cells), primary follicles (enlarged oocyte completely surrounded by 1 to 2 layers of cuboidal follicular cells), preantral follicles (enlarged oocyte surrounded by 2 or more layers of granulosa cells with no antrum), and antral follicles (distinguished by the presence of an antrum within the granulosa cell layers enclosing the oocyte) as described by Cheng et al. (2002). Only primordial, primary, preantral, and antral follicles with a spherical nucleus that was visible in the section were counted (Figure 1). The number of each type of follicle was corrected according to the nuclear diameter and thickness of the cut, as described by Gougeon and Chainy (1987) and the following formula:

$$
\begin{aligned}
\text { no. corrected } & =\text { follicle counted } \\
& \times \frac{\text { cut thickness }}{\sqrt{\text { cut thickness }+\frac{(d m)^{2}}{2}-\frac{(d m)^{2}}{4}}},
\end{aligned}
$$

where $d m=$ nuclear diameter.

After qualitative evaluation of the slides, images of testicular parenchyma were retrieved from a video camera linked to light microscope (EVOS XL Core Cell Imaging System) and were analyzed with Image J1.48 software (National Institutes of Health) at magnification of $40 \times$ (Figure 2). Testicular volume of bovine fetuses was equal to fresh left testis weight $(\mathrm{g})$, assuming testicular density is 1 (Russell et al., 1990). The volumetric proportion of testicular parenchyma components was measured by counting points. Twenty randomly selected fields per fetal testis were used. Briefly, a grid of 450 evenly distributed test points was superimposed over the screen image of every microscopic field studied. In each fetus, the number of test points overlying the component of interest (seminiferous cords or interstitium) was counted. The volumetric proportions, described in percentages, were calculated based on a total of 9,000 points per fetus.

The diameter of the seminiferous cords was estimated as the average value of measuring 2 perpendicular diameters (maximum and minimum) from 30 randomly chosen cross-sections of seminiferous cords per testis. 
A

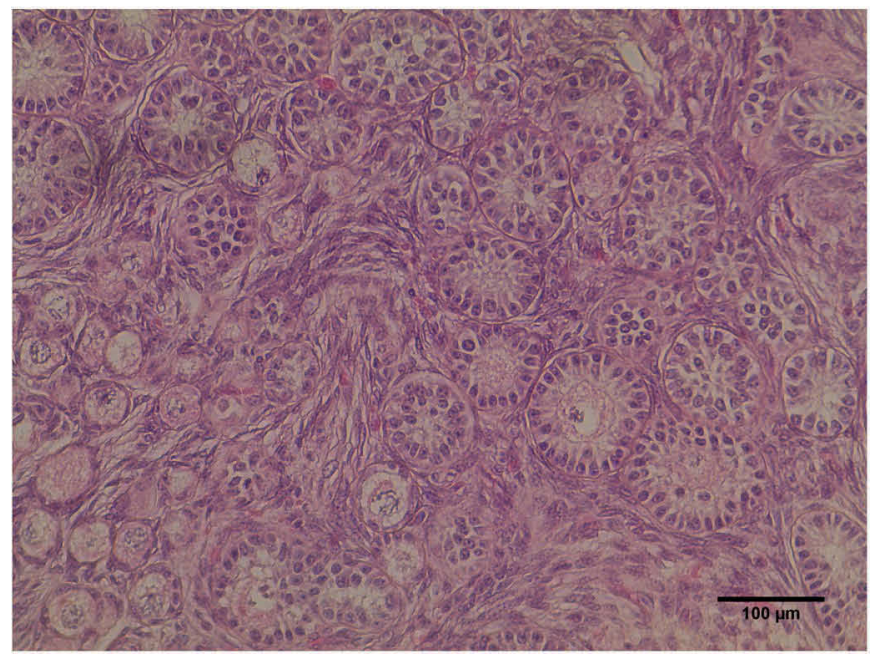

B

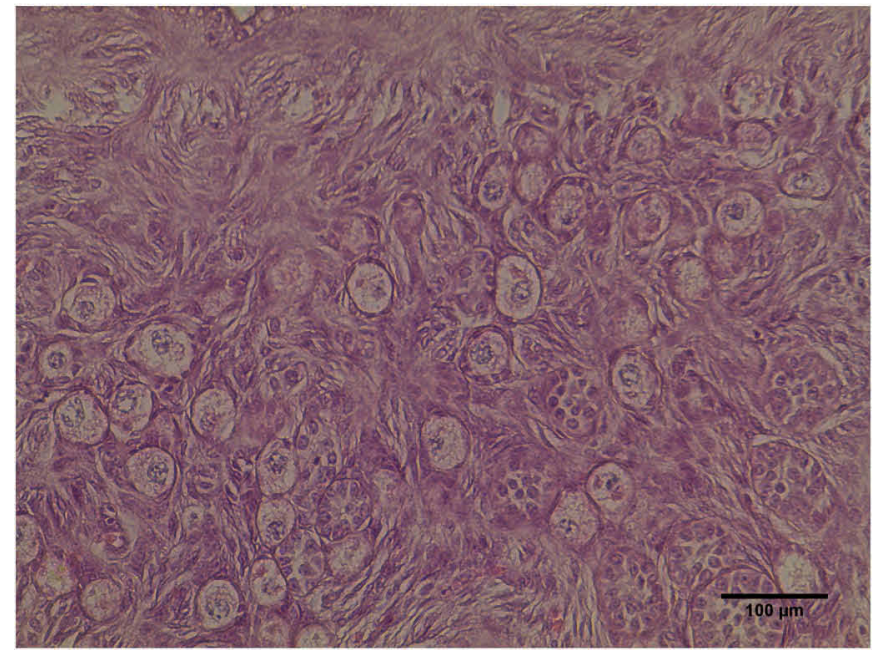

Figure 1. Fetal ovary of a representative bovine fetus from the (A) high- and (B) moderate-intake cows at $268 \mathrm{~d}$ of gestation. Color version available online.

Seminiferous cords were assumed to be cylindrical and their lengths $(L)$ were estimated as described by Marshall and Plant (1996) in the following formula:

$$
L=V_{s} /\left[\pi \times\left(D_{s} / 2\right)^{2}\right],
$$

$V_{s}=($ volumetric proportion of seminiferous cords $)$

$\times$ (testicular volume),

where $D_{s}$ is the diameter of the seminiferous cords.

A

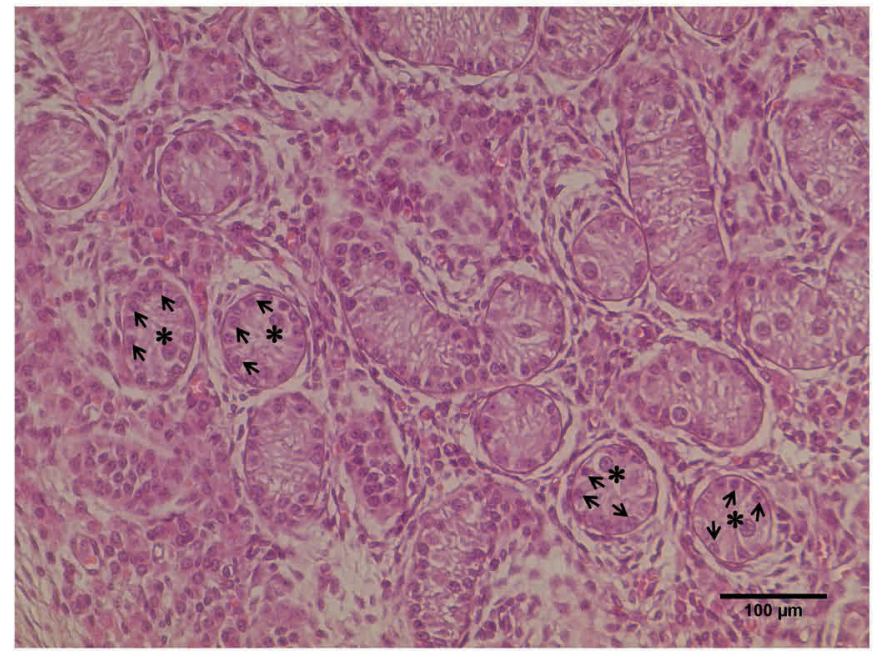

\section{Quantitative Real-Time Transcription PCR Analysis}

Total RNA was isolated from $50 \mathrm{mg}$ of right ovaries and testicles by using RNeasy Mini Kit (Qiagen, Valencia, CA) according to the manufacturer's recommendations. Additional treatment with DNase was performed on the columns using the RNase-free DNase Set (Qiagen), according to the manufacturer's recommendations. The RNA concentrations were checked by NanoVue Plus Spectrophotometer (GE Healthcare, Munich, Germany) with an optimal 260/280 ratio be-

B

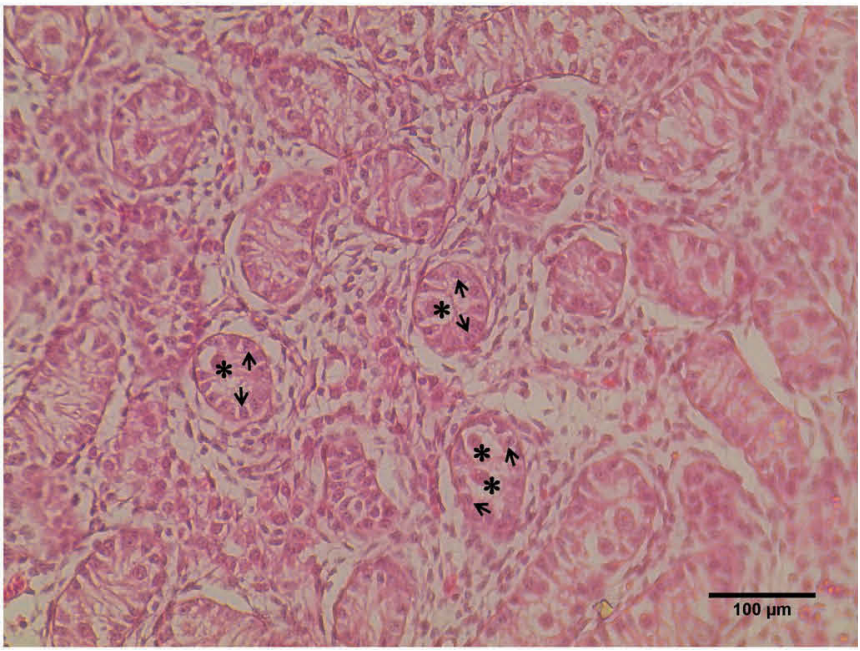

Figure 2. Testicular parenchyma in a bovine fetus from (A) high- and (B) moderate-intake cows at 199 d of gestation. Each seminiferous cord is composed of pre-spermatogonia $(*)$ centrally located in the middle of the cord and pre-Sertoli cells (arrows) located at the periphery. Color version available online. 
tween 1.8 and 2.1. Intact $28 \mathrm{~S}$ and $18 \mathrm{~S}$ rRNA subunit integrity was assessed by agarose gel electrophoresis to detect degradation of the RNA.

Reverse transcription was performed using GoScript Reverse Transcription System (Promega, Madison, $\mathrm{WI}$ ) and oligo (dT) primers (Invitrogen, Carlsbad, $\mathrm{CA}$ ). The cDNA concentrations from the samples were estimated on a NanoVue Plus spectrophotometer (GE Healthcare). Finally, the cDNA samples were stored at $-20^{\circ} \mathrm{C}$ for analysis.

The gene target and reference sequence was recovered from Bos taurus nucleotide sequences obtained from the GenBank database. The following genes were evaluated in the fetal ovary: $E S R-\alpha, F H S R, B M P R$-2, GDF-9, TGFßR1, TGFß1, Bax, CASP3, Bcl2, StAR, and P450arom. In the fetal testis, samples were evaluated for the following genes: AR, LHCGR, IGF1, IGF1R, IGF2, Bax, Bcl2, CASP3, StAR, and HSD17ß3. In fetal pituitary samples, $F S H B$ and the $L H B$ genes were analyzed. These gene sequences were used to construct primers by the PrimerQuest program provided by Integrated DNA Technologies, Inc. (Coralville, IA). Glyceraldehyde 3-phosphate dehydrogenase and $\beta-2$ microglobulin $(B 2 M)$ genes were used as the reference gene for normalization in pituitary and gonadal tissues, respectively. These genes had the lowest gene-stability measure $(\mathbf{M})$ compared with $\beta$-actin and ubiquitin $\mathrm{C}$ using geNorm program (Vandesompele et al., 2002). The $G A P D H$ and $B 2 m$ had $\mathrm{M}=0.3$ versus $\beta$-actin and ubiquitin $\mathrm{C}$ with $\mathrm{M}=0.8$. The primer pairs of each target and reference genes are listed in Table 1.

Quantitative real-time PCR (qRT-PCR) reactions were performed in different wells and in duplicates using SYBR Green detection with GoTaq PCR Master Mix (Promega) following the manufacturer's instructions in an ABI Prism 7300 Sequence Detection System thermocycler (Applied Biosystems, Foster City, CA). The reaction consisted of an initial step at $95^{\circ} \mathrm{C}$ for 10 min, a second step of 40 cycles with the same temperature for $15 \mathrm{~s}$, and a final extension step at $60^{\circ} \mathrm{C}$ for 60 s. After the amplification cycles, an additional gradient step from 60 to $95^{\circ} \mathrm{C}$ was used to obtain a melting curve. The measurement in qRT-PCR experiment is expressed in cycles to threshold $\left(\mathrm{C}_{t}\right)$ of $\mathrm{PCR}$, a relative value that represents the cycle number at which the amount of amplified cDNA reaches the threshold level. Prior to quantification by qRT-PCR, the amplification efficiency and optimal primer concentration were determined for each gene using serial dilution of cDNA. The PCR efficiencies for all primers pairs were obtained using the formula $\mathrm{E}=10^{(-1 / \text { slope })} \times 100$, where $\mathrm{E}$ is efficiency and slope is the gradient of dilution series and are summarized in Table 1.

\section{Statistical Analysis}

The experimental design was completely randomized with a $2 \times 2$ (female fetuses) and $3 \times 2$ (male fetuses) arrangement of treatments. Fetal BW, the weight of their reproductive organs, and histological data were analyzed by using the GLM procedures (SAS Institute Inc., Cary, NC). Day of gestation, maternal intake, and their interaction were included as fixed effects in the model. Means were compared by the Tukey test to the level of $5 \%$.

Statistical analysis of $\mathrm{C}_{t}$ data for each fetal sex was realized using the \%QPCR_MIXED macro (https:// www.msu.edu/ steibelj/JP_files/QPCR.html) developed to generate codes in SAS PROC MIXED suitable to analyze data from qRT-PCR, assuming independent random effects for reference and target genes in each biological replicate (Steibel et al., 2009). This statistical method is more accurate, powerful, and flexible than existing alternatives for analysis of relative quantification qRT-PCR data (Steibel et al., 2009). The following model was used:

$$
y_{g i k r}=T G_{g i}+C_{g i k}+D_{i k}+e_{g i k r},
$$

where $y_{\text {gikr }}$ corresponds to the $\mathrm{C}_{\mathrm{t}}$ value obtained from the thermocycler software for the gth gene (reference or targets) from the $r$ th well, which corresponds to the $k$ th animal submitted to the $i$ th treatment (days of gestation and maternal intake combination); $T G_{g i}$ is the effect of the $i$ th treatment on the expression of gene $g$; $C_{\text {gik }} \sim N\left(0, \sigma_{C}^{2}\right)$ is the gene-specific random effect of the $k$ th animal; $D_{i k} \sim N\left(0, \sigma_{D}^{2}\right)$ is the sample-specific random effect (common to reference and target genes); and $e_{g i k r} \sim N\left(0, \sigma_{e}^{2}\right)$ is the residual term.

Relative mRNA abundance (fold change) was estimated using the $2^{-\Delta \mathrm{Ct}}$ method of Livak and Shmittgen (2001). For each target gene, the comparison of gene expression across treatments, inside each fetal sex, was performed by the CONTRAST statement of the GLM procedure using Student's $t$-test to the level of $5 \%$. Relative mRNA expression for genes that exhibited differential expression across treatments were presented in box plots graphs (median, maximum, minimum, and interquartile range). The entire statistical results for each pairwise contrast of interest across treatments are shown in Supplemental Tables S2 and S3; http:// dx.doi.org/10.3168/jds.2015-9673). To validate our gene expression results facing the limited sample size, permutation test-based $P$-values (Supplemental Tables S2 and S3; http://dx.doi.org/10.3168/jds.2015-9673) were calculated using 1,000 resamplings (Manly, 1997; 
Sun et al., 2014). These permutations were performed by shuffling $\mathrm{Ct}$ values from different treatments, maternal intake, and days of gestation, separately within each gene. These analyses confirmed the consistency of our qRT-PCR results. Analogously, the mentioned permutation tests were also applied to fetal reproductive organs weight and histological data analysis (Supplemental Table S4; http://dx.doi.org/10.3168/ jds.2015-9673) and have also confirmed the significant statistical results. Despite this, the authors suggest the use of larger sample sizes in future research.

\section{RESULTS}

\section{Fetal Growth and Gonadal Development}

Fetal and reproductive organs weights in females and males are presented in Tables 2 and 3, respectively.

Table 1. Gene names, primer pair sequences, annealing temperatures, and amplification efficiencies of each target

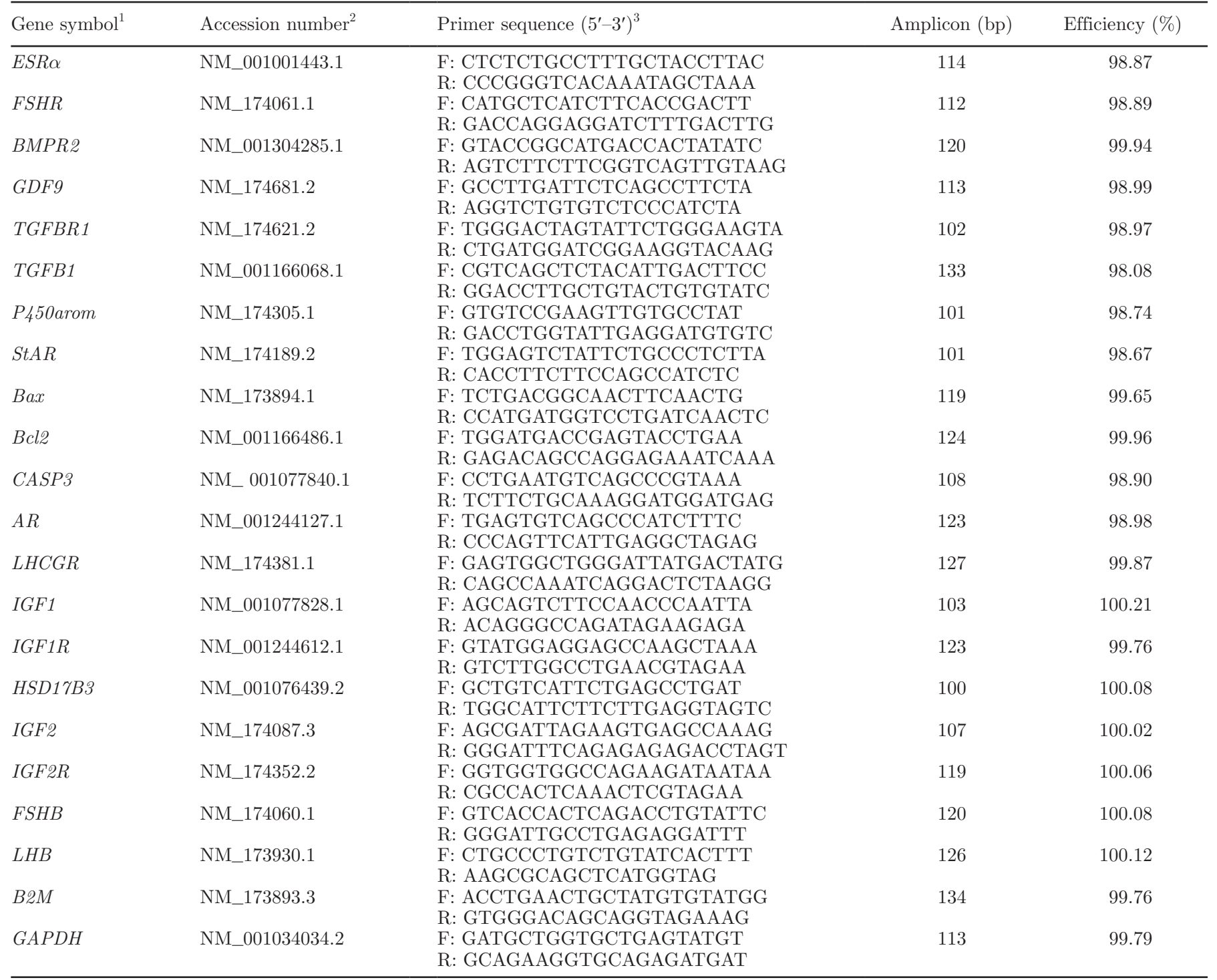

${ }^{1}$ Estrogen receptor $\alpha(E S R \alpha)$, follicle stimulating hormone receptor $(F S H R)$, bone morphogenetic protein receptor, type II $(B M P R 2)$, growth differentiation factor $(G D F 9)$, transforming growth factor beta 1 (TGFB1), transforming growth factor $\beta$ receptor 1 (TGFBR1), cytochrome P450 aromatase (P450arom), steroidogenic acute regulator (Star), BCL2-associated X protein (Bax), B cell/lymphoma-2 family (Bcl2), androgen receptor $(A R)$, luteinizing hormone/choriogonadotropin receptor $(L H C G R$ ), insulin-like growth factor 1 (IGF1), insulin-like growth factor 1 receptor $(I G F 1 R), 17$-beta-hydroxysteroid dehydrogenase 3 (HSD17B3), insulin-like growth factor 2 (IGF2), insulin-like growth factor 2 receptor $(I G F 2 R)$, follicle stimulating hormone, $\beta$ polypeptide $(F S H B)$, luteinizing hormone $\beta$ polypeptide $(L H B), \beta$-2-macroglobulin $(B 2 M)$.

${ }^{2}$ Accession number at GenBank (http://www.ncbi.nlm.nih.gov).

${ }^{3} \mathrm{~F}=$ forward; $\mathrm{R}=$ reverse. 
Table 2. Effects of maternal intake and days of gestation on bovine female fetuses characteristics

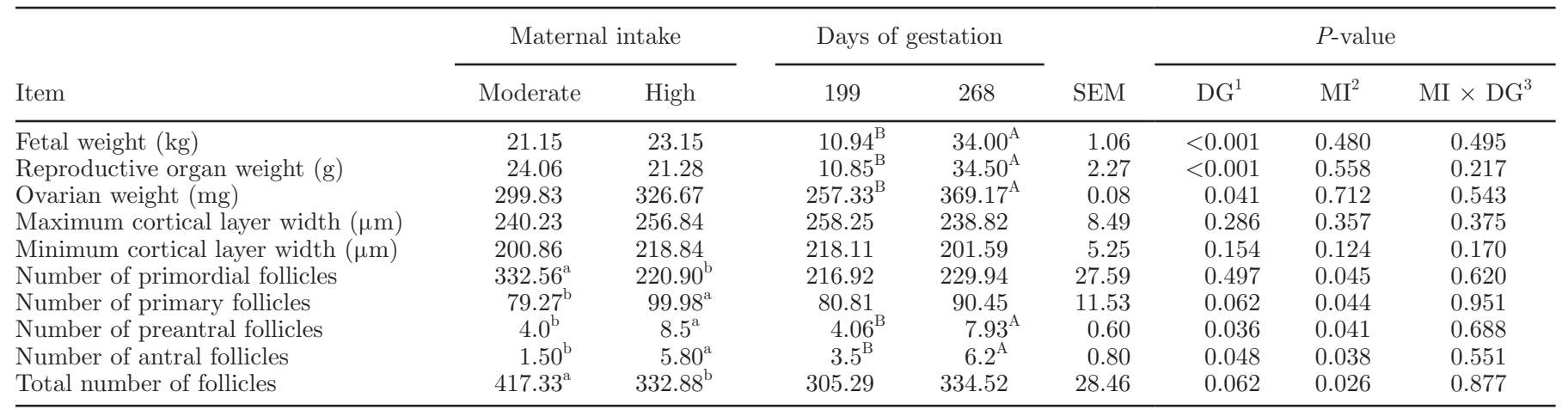

${ }^{\mathrm{a}, \mathrm{b}}$ Different lowercase letters represent statistical difference $(P<0.05)$ between maternal intakes.

${ }^{\mathrm{A}, \mathrm{B}}$ Different uppercase letters represent statistical difference $(P<0.05)$ between days of gestation.

${ }^{1}$ Days of gestation main effects.

${ }^{2}$ Maternal intake main effects.

${ }^{3}$ Interaction between maternal intake and days of gestation.

Irrespective of the sex of fetuses, no effect was found of maternal intake on fetal or reproductive organ weights and no interaction between maternal intake and DG. In contrast, a DG effect was found on fetal, reproductive organs, and ovarian and testicular weights as expected due to normal fetal growth during gestation.

The estimated numbers of primordial and total follicles were lower $(P=0.045 ; P=0.026$, respectively $)$ in fetuses from $\mathrm{H}$ than $\mathrm{M}$ intake cows (Table 2). No difference was found $(P=0.497)$ between DG on number of primordial follicles. Interestingly, a tendency appeared to occur for the number for primary follicles to increase $(P=0.062)$ with fetal age corresponding to DG. We did not observe an interaction between maternal intake and DG on primordial $(P=0.620)$, primary $(P=0.951)$, preantral $(P=0.688)$, and antral $(P=$ $0.551)$ follicle numbers (Table 2$)$. Primary $(P=0.044)$, preantral $(P=0.041)$, and antral follicle $(P=0.038)$ numbers were higher in fetal ovaries derived from $\mathrm{H}$ intake cows, with no interaction between maternal intake and DG. Moreover, DG affected preantral $(P=0.036)$ and antral follicles $(P=0.048)$ numbers, as these were higher at $268 \mathrm{DG}$.

Maternal nutrition affected diameter $(P=0.034)$, lengths $(P=0.042)$, and volumetric proportion of seminiferous cords $(P=0.035)$, but no effect of interaction between maternal intake and DG was detected. Diameter and length of seminiferous cord did not differ ( $P=0.446 ; P=0.524$, respectively) with DG (Table $3)$. Moreover, volumetric proportion of seminiferous cords was decreased $(P=0.045)$ with DG, whereas interstitium volumetric proportion was higher $(P=$ $0.034)$ at 199 and 241 DG compared with 139 DG (Table 3).

\section{Fetal Pituitary LH $\beta$ and FSH $\beta$ Gene Expression}

Maternal nutrition altered the expression levels of FSHB $(P=0.004)$ in fetal pituitary of females, whereas $L H B$ gene expression did not differ $(P=0.18)$ with maternal intake. The FSHB gene had greater $(P<0.05)$ values in the fetal pituitary of females from $\mathrm{H}$ intake cows compared with $\mathrm{M}$ intake cows, at 199 and 268 DG (Figure 3$)$. We observed interaction $(P=0.008)$ between maternal intake and DG on FSHB gene expression in female fetuses. The $F S H B$ expression was higher $(P<0.01)$ at 268 than at 199 DG in female fetuses from both maternal intake groups (Figure 3 ).

The FSHB gene expression levels were similar between maternal intake in fetal pituitary of males $(P=$ $0.59)$, with an effect of DG $(P=0.012)$ and no significant interaction between maternal intake and DG $(P$ $=0.42)$. As observed for $F S H B$, no difference in $L H B$ gene expression levels $(P=0.25)$ was detected between maternal intake groups, but an effect $(P=0.001)$ of DG was found. The expression level of FSHB and $L H B$ was higher $(P<0.01)$ at 199 and 241 DG compared with 139 DG in male fetuses from both maternal intake groups (Figure 4).

\section{Fetal Ovary Gene Expression}

Maternal nutrition altered ovarian P450arom, StAR, BMPR2, TGFBR1, GDF9, FSHR, Bax, and CASP3 expression levels. Ovarian fetuses from $\mathrm{H}$ intake cows had higher $(P<0.05)$ expression of these genes compared with $\mathrm{M}$ intake cows, at 199 and 268 DG (Figure 5). The gene expression levels of P450arom and StAR were higher $(P<0.01)$ at 268 than 199 DG in both maternal 


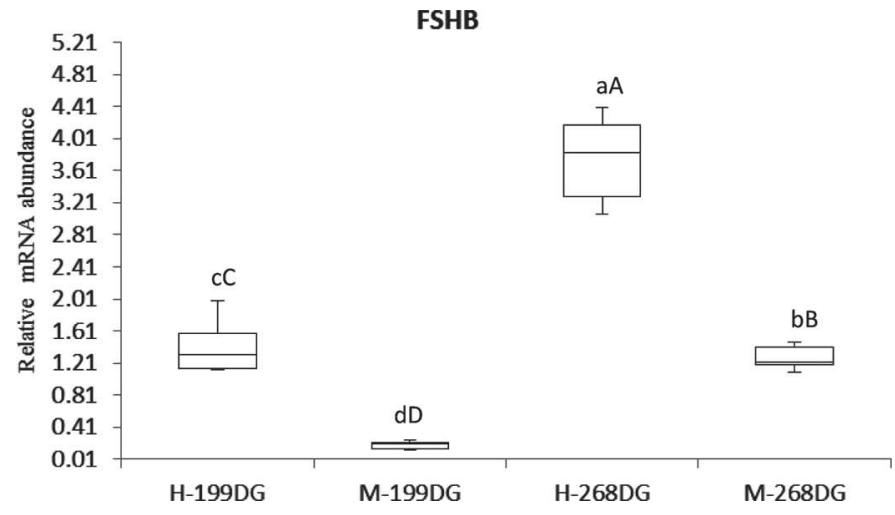

Figure 3. Box plot graphs (median, maximum, minimum, and interquartile range) for relative mRNA abundance of FSHB in pituitary gland of female fetuses from high- $(\mathrm{H})$ and moderate- $(\mathrm{M})$ intake cows at 199 and $268 \mathrm{~d}$ of gestation (DG). ${ }^{\mathrm{a}-\mathrm{d}}$ Different lowercase letters represent difference $(P<0.05)$ between maternal intakes within DG. ${ }^{\mathrm{A}-\mathrm{D}}$ Different uppercase letters represent difference $(P<0.01)$ between DG within maternal intake.
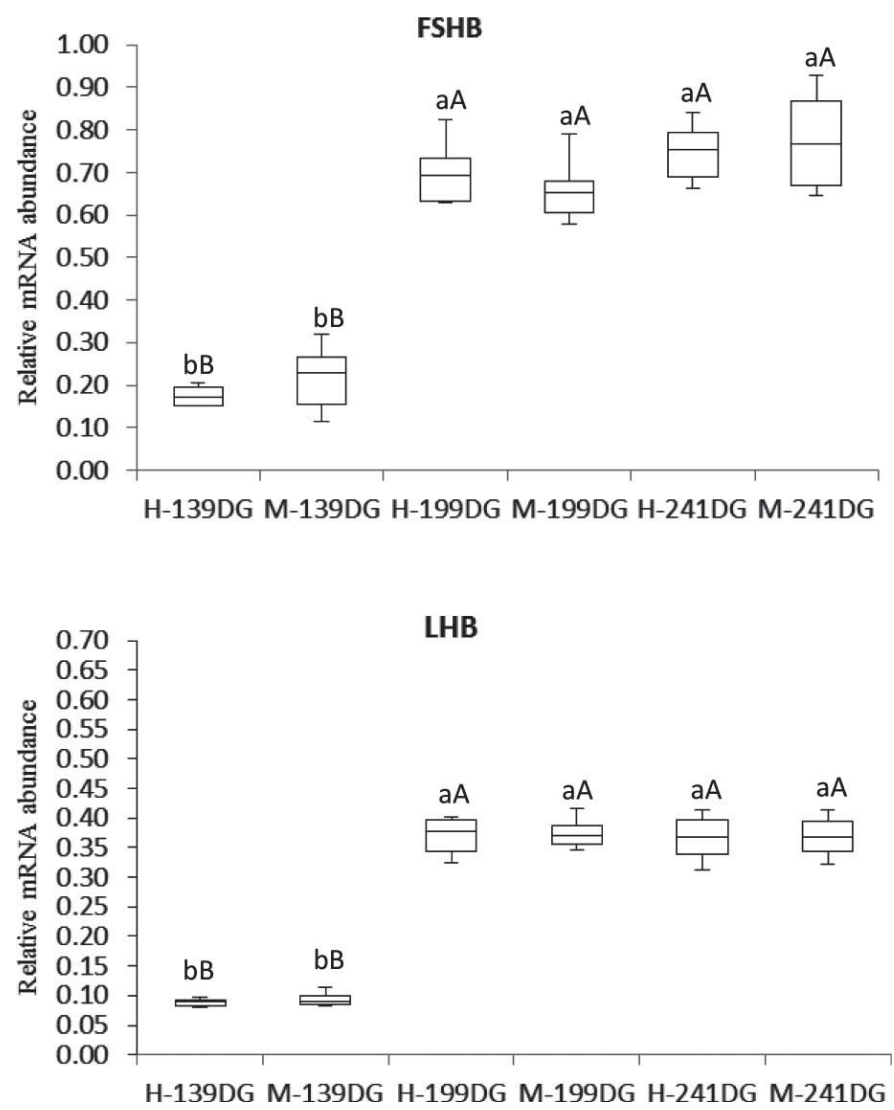

Figure 4. Box plot graphs (median, maximum, minimum, and interquartile range) for relative mRNA abundance of $F S H B$ and $L H B$ in pituitary gland of male fetuses from high- $(\mathrm{H})$ or moderate- $(\mathrm{M})$ intake cows at 139, 199, and $241 \mathrm{~d}$ of gestation (DG). ${ }^{\mathrm{a}, \mathrm{b}}$ No difference between maternal intakes within DG, which were represented by lowercase letters. ${ }^{\mathrm{A}, \mathrm{B}}$ Different uppercase letters represent difference $(P<$ 0.01 ) between DG within maternal intake.

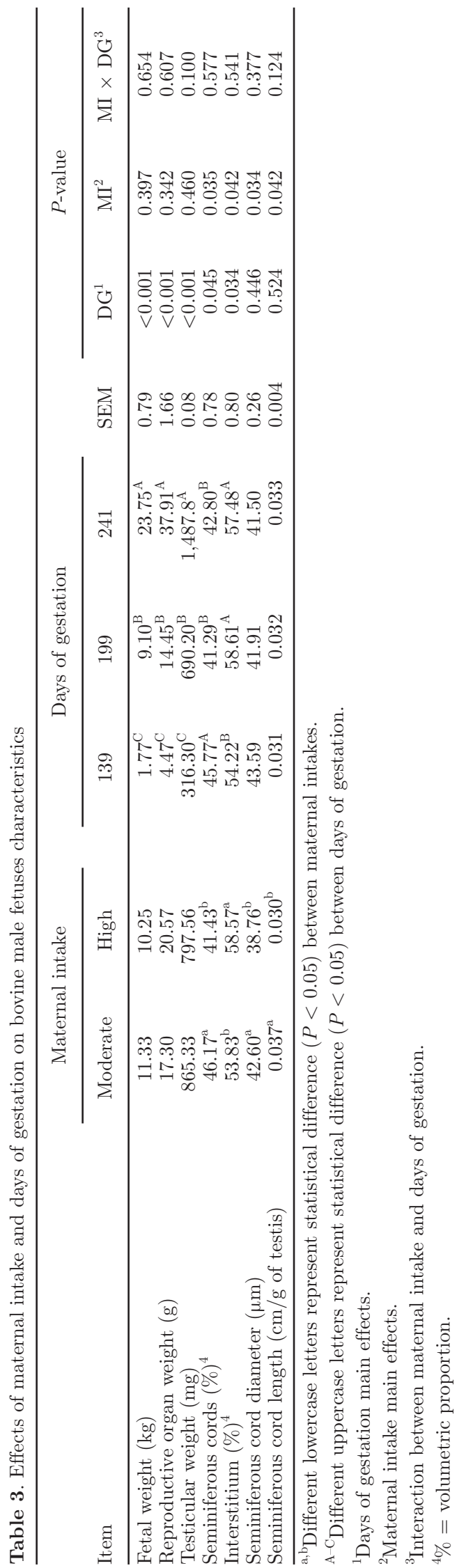

Journal of Dairy Science Vol. 99 No. 4, 2016 
intake groups. In contrast, $C A S P 3$ and Bax genes had greater $(P<0.001)$ values at $199 \mathrm{DG}$ compared with 268 DG in both maternal intake groups (Figure 5).

\section{Fetal Testis Gene Expression}

Maternal nutrition altered testicular expression of StAR and HSD17B3 genes. Fetuses from M intake cows had higher expression $(P<0.01)$ of these genes compared with $\mathrm{H}$ intake cows at 139 and 199 DG (Figure $6)$. As observed for expression of key steroidogenic enzymes, IGF1, IGF2, and IGF1R genes had greater expression in fetal testis derived from $M$ intake than $\mathrm{H}$ intake cows, irrespective of DG. Moreover, testicular expression of $I G F 1, I G F 2$, and $I G F 1 R$ were higher at 139 DG than at 199 DG and at 241 DG than at 199 DG in both maternal intake groups (Figure 6).

$\mathbf{A}$

StAR

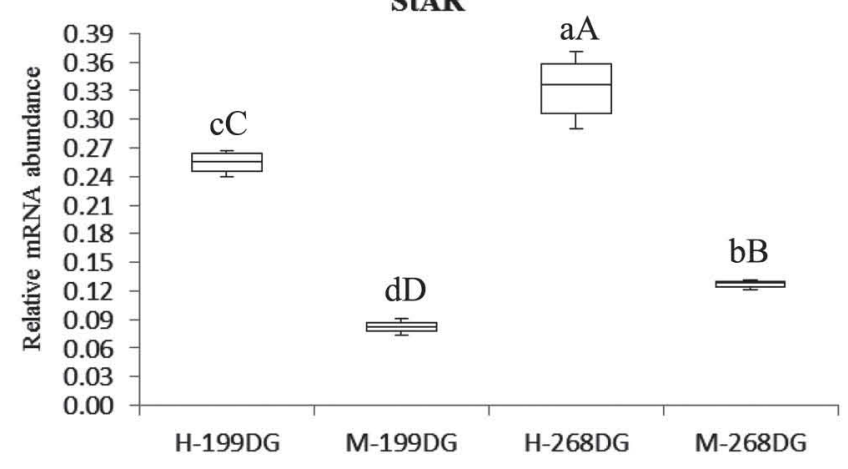

C

BMPR2

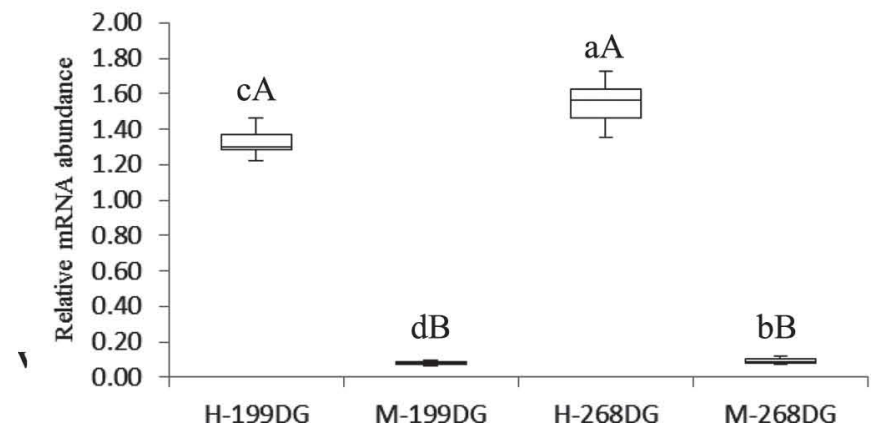

\section{DISCUSSION}

Maternal nutrition has been considered as a major cause of developmental programming (Chavatte-Palmer et al., 2014; William et al., 2014). To our knowledge, the current study is the first to provide evidences regarding the effects of maternal overnutrition on pituitary-gonadal gene expression and gonadal germ cell development in cattle fetuses at mid- and lategestation. It is noteworthy, however, that small sample size was a major limitation of this study. Overnutrition during gestation resulted in upregulation of genes involved in ovarian folliculogenesis, steroidogenesis, and pro-apoptosis. Moreover, we observed a reduction in the estimated numbers of primordial and total follicles and increased primary, preantral, and antral follicles in fetuses from $\mathrm{H}$ intake cows compared with $\mathrm{M}$ intake. In contrast, we observed downregulation of steroidogenic

B

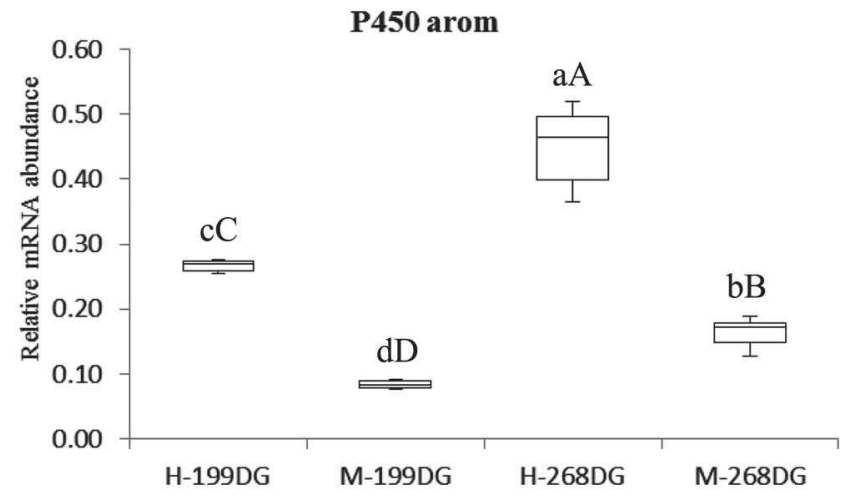

D

TGFBR1

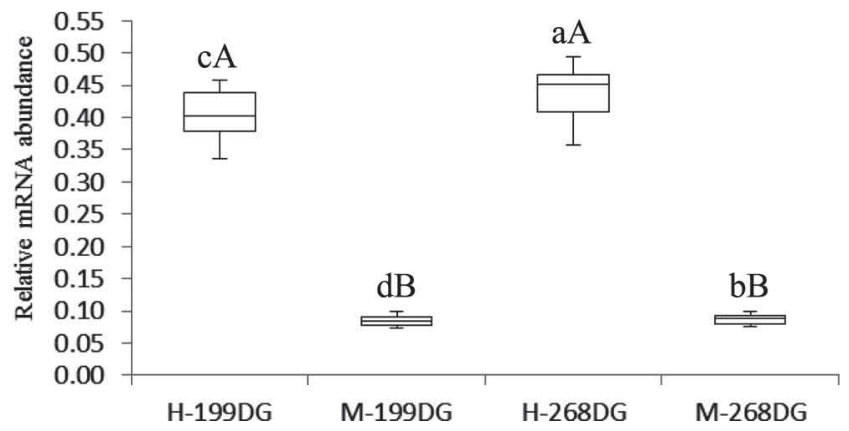

Figure 5. Box plot graphs (median, maximum, minimum, and interquartile range) for relative mRNA abundance of (A) StAR, (B) P450arom, (C) BMPR2, (D) TGFBR1 (E) GDF9, (F) FSHR, (G) CASP3, and (H) Bax in fetal ovaries from high- (H) and moderate- (M) intake cows at 199 and $268 \mathrm{~d}$ of gestation $(\mathrm{DG}) .{ }^{\mathrm{a}-\mathrm{d}}$ Different lowercase letters represent difference $(P<0.05)$ between maternal intakes within DG. ${ }^{\mathrm{A}-\mathrm{D}}$ Different uppercase letters represent difference $(P<0.01)$ between DG within maternal intake. 
and growth factors genes in male fetuses from $\mathrm{H}$ intake cows compared with $\mathrm{M}$ intake. This downregulation of gene expression was accompanied by a decrease in diameter, length, and volumetric proportion of seminiferous cords.

The effects were not accompanied by changes in fetal BW and reproductive organ and gonad weights, because weights were not affected by maternal nutrition and reinforce the concept that maternal nutrition can affect fetal development independent of changes in fetal weight or in organ mass (Harding and Johnston, 1995; Hawkins et al., 2000). The effects might persist until adulthood according to literature evidence in other species (Bernal et al., 2010; Connor et al., 2012; Guzmán et al., 2014) and should be the focus of future research in cattle. Our data point to distinct effects of maternal overnutrition according to the sex of the fetus.

$\mathbf{E}$

\section{GDF9}

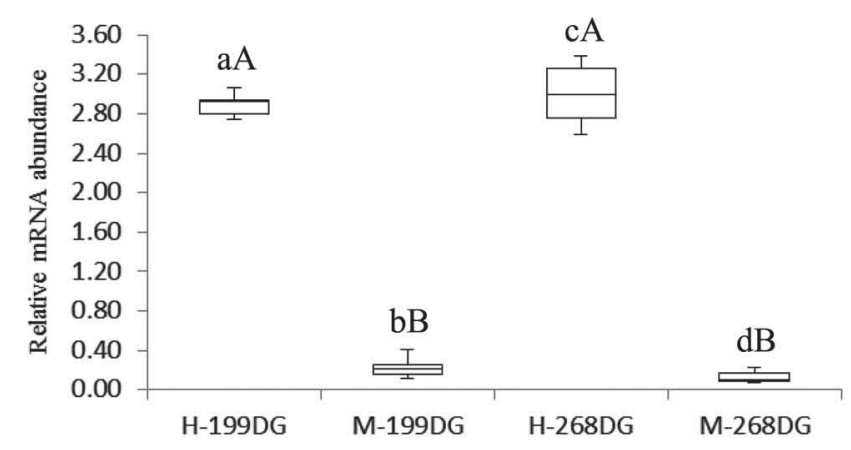

G

CASP3

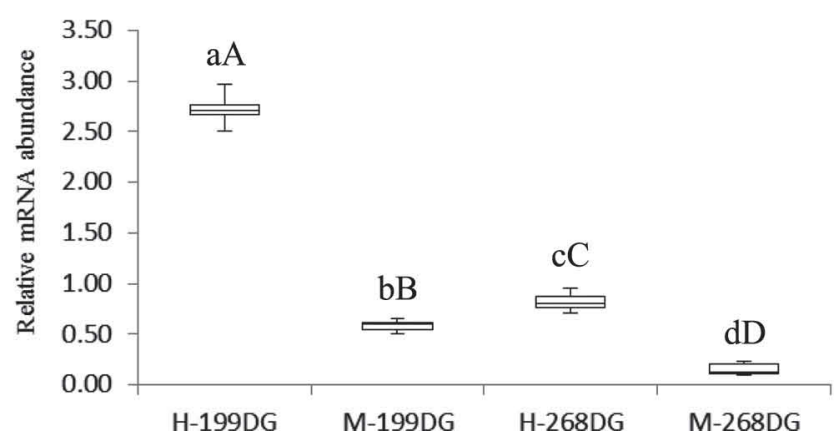

Although we did not measure fetal or maternal endocrine profiles, it is likely that the availability of nutrients, insulin, and IGF-I is high in the circulation of overnourished cows and would result in a higher fetal nutrient supply with subsequent changes, not only in fetal hormones levels (e.g., insulin, IGF-I) but also in metabolic pathways, which in turn could alter gene expression in fetal gonads. Indeed, animal studies have shown that maternal overnutrition alters fetal endocrine status (Zhang et al., 2011; Seet et al., 2015) and gene expression (Bruce et al., 2009; Tong et al., 2009). In humans, maternal obesity is associated with alteration in the homeostasis of cytokines and adipokines, such as adiponectin (Schmatz et al., 2010). Adiponectin influences placental transfer of nutrients and placental insulin-stimulated AA uptake in pregnancy (Aye et al., 2013). Moreover, in animal models, Tenenbaum-Gavish

F

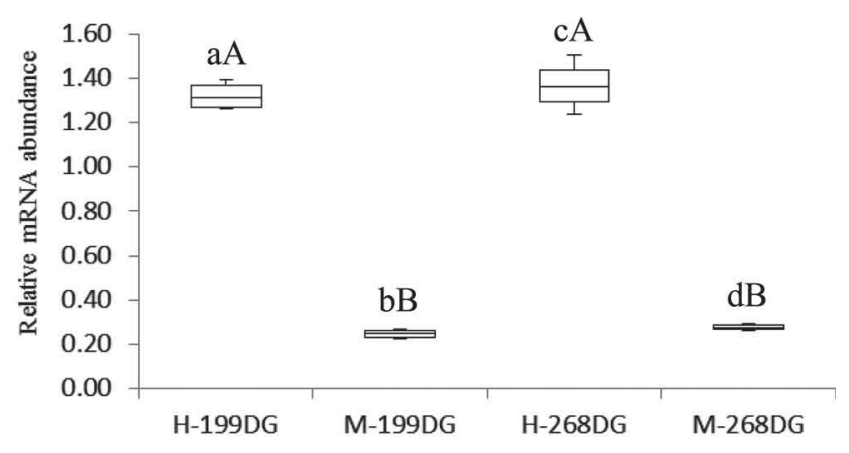

H

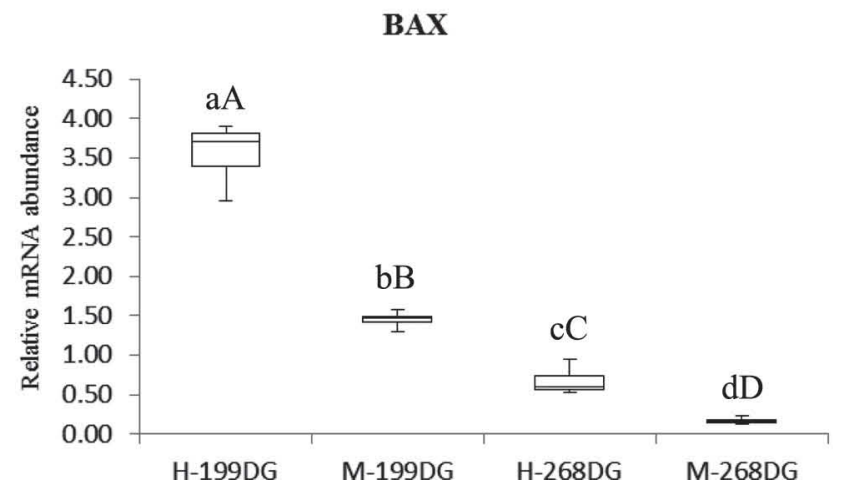

Figure 5 (Continued). Box plot graphs (median, maximum, minimum, and interquartile range) for relative mRNA abundance of (A) StAR, (B) P450arom, (C) BMPR2, (D) TGFBR1 (E) GDF9, (F) FSHR, (G) CASP3, and (H) Bax in fetal ovaries from high- (H) and moderate- (M) intake cows at 199 and $268 \mathrm{~d}$ of gestation $(\mathrm{DG}) .{ }^{\mathrm{a}-\mathrm{d}}$ Different lowercase letters represent difference $(P<0.05)$ between maternal intakes within DG. ${ }^{\mathrm{A}-\mathrm{D}}$ Different uppercase letters represent difference $(P<0.01)$ between DG within maternal intake. 

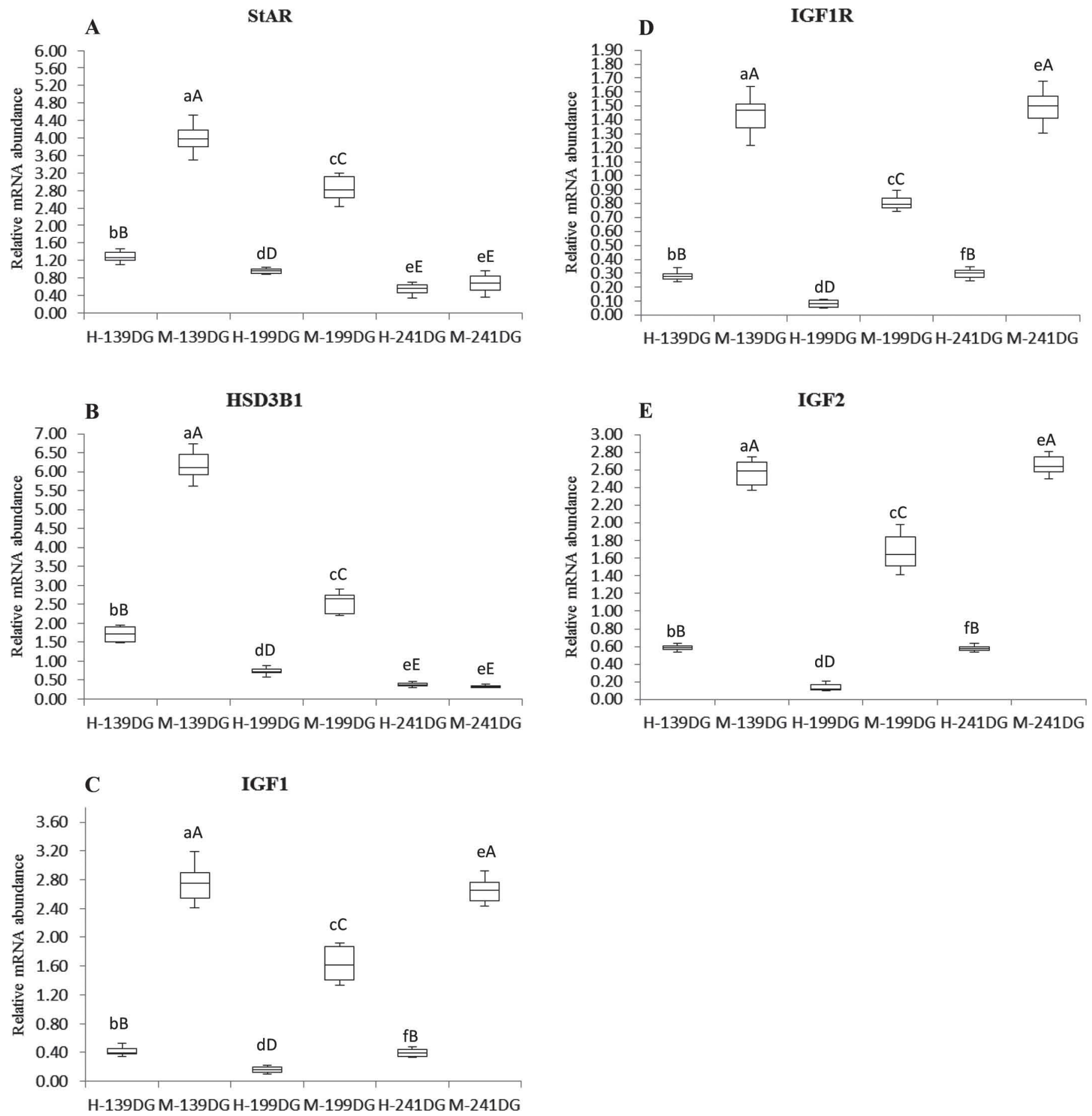

Figure 6. Box plot graphs (median, maximum, minimum, and interquartile range) for relative mRNA abundance of (A) StAR, (B) HSD3B1, (C) IGF1, (D) IGF1R, and (E) IGF2 in fetal testis from high- (H) and moderate- (M) intake cows at 139, 199, and 241 d of gestation (DG). ${ }^{\mathrm{a}-\mathrm{f}}$ Different lowercase letters represent difference $(P<0.05)$ between maternal intakes within DG. ${ }^{\mathrm{A}-\mathrm{E}}$ Different uppercase letters represent difference $(P<0.01)$ between DG within maternal intake.

and Hod (2013) reported that adiponectin administration causes downregulation of activity and expression of key placental nutrient transporters; it also binds to the adiponectin receptor- 2 on the trophoblast cell and activates p38 MAPK and PPAR- $\alpha$, which inhibits the insulin/IGF-I signaling pathway. Overall, the effects 
of overnourished cows on fetal pituitary-gonadal gene expression and development should be further investigated.

\section{Effects of Maternal Nutrition on Fetal Pituitary Gland}

In our study, maternal $\mathrm{H}$ intake was associated with enhanced expression of FSHB gene in the pituitary gland of female fetuses. We observed expression FSHB was higher at 199 and $268 \mathrm{DG}$ in female fetuses from $\mathrm{H}$ intake cows, which indicates that the FSHB expression may be affected by timing of maternal overnutrition. This supports the study by Rhind et al. (2001), which showed that development of the hypothalamic-pituitary axis and the synthesis of gonadotropins can be sensitive to pre-natal nutrition in the sheep fetus. By contrast, the expression of FSHB in the pituitary gland of male fetuses in our study was similar between $\mathrm{H}$ and $\mathrm{M}$ intake groups, which suggest that gonadotroph cells of male and female fetuses respond differently to maternal nutrition. No effect was found of maternal intake on $L H B$ gene expression in both fetal sexes, which suggests that this hormone is not involved in the observed nutritionally induced changes in ovarian and testis development during the gestational period evaluated.

\section{Effects of Maternal Nutrition on Fetal Gonads}

Maternal over nutrition during mid- and late-gestation disturbs ovarian follicular growth and number of follicles with an increment in the number of primary, preantral, and antral follicles and reduction in the estimated number of primordial and total follicles, regardless of DG. These changes may be underpinned by observed alterations in the expression levels of key genes involved in folliculogenesis (BMPR2, TGFBR1, GDF9, and FSHR), steroidogenesis (P450arom and $S t A R)$, and apoptosis (Bax, CASP3).

Increased ovarian FSHR and pituitary FSHB expression may also positively affect preantral and antral follicular numbers. The hormone FSH and its receptor FSHR play an important role in follicle progression from primary to advanced stages of follicular development (Richards, 1994). Our results are consistent with previous studies where FSH and its receptor stimulated follicular growth in ovaries of bovine fetuses (Bao et al., 1997; Tanaka et al., 2001). The emerging hypothesis from our study is that maternal overnutrition may trigger increased pituitary expression of FSHB and increased ovarian expression of FSHR with consequence to folliculogenesis, observed as increased numbers of preantral and antral follicles.

The reduction in the total number of ovarian follicles at both $\mathrm{DG}$ in fetuses from $\mathrm{H}$ compared with fetuses from $\mathrm{M}$ intake cows can be largely attributed to a reduction in the number of primordial follicles. These results may reflect a decrease in proliferation as well as an increase in atresia of germ cells that begins at 60 DG and finishes between 150 to $170 \mathrm{DG}$, when the number of germ cells in the bovine ovary is fixed (Erickson, 1966). This hypothesis is supported by a previous study that reported maternal high-fat diet induced follicular apoptosis in rabbit's female offspring (Léveillé et al., 2014). Bcl2, its antagonist Bax, and CASP3 are key regulators of apoptosis (Hussein, 2005), and they are expressed in ovaries of mouse fetuses, suggesting their role in atresia (Nandedkar and Dharma, 2001). The CASP3 pathways seem to be one of the most important cell death mechanisms in human fetuses (Poljicanin et al., 2013). We observed increased Bax and CASP3 expression with no alteration of Bcl2 expression in fetal ovaries from $\mathrm{H}$ intake cows. The imbalance of anti- and pro-apoptotic genes could explain the reduction of primordial and total number of follicles in fetuses from $\mathrm{H}$ intake cows. Previous studies reported that in rats (Yoon et al., 2002) and humans (Kugu et al., 1998), increased Bax expression was correlated with follicular atresia. Moreover, studies in mouse fetal ovary showed that apoptosis of germ cells is correlated with increased levels of Bax in the absence of any change in Bcl2 levels (Felici et al., 1999). It is possible that maternal overnutrition could lead to oxidative stress resulting in greater loss of germ cells and follicles during gestation, which in turn may reduce ovarian reserve and subsequent fertility in their offspring.

Genes of TGFB superfamily are essential growth factors that regulate mammalian folliculogenesis (Paradis et al., 2009; Piotrowska et al., 2013). The TGFB1 expression did not differ between the maternal intake groups and DG. However, the differential expression of GDF9 is likely to underpin the observed differences in follicular growth. Higher numbers of follicles in advanced stages of follicular growth were observed in $\mathrm{H}$ intake cows. In agreement, previous studies have shown that GDF9 is required for primordial to primary transition in bovine and rat follicular growth (Bodensteiner et al., 1999; Vitt et al., 2000). Also, GDF9 enhances the progression of early- to late-stage follicular growth in rats (Nilsson and Skinner, 2002; Martins et al., 2008). We detected higher expression of BMPR2 and TGF$B R 1$ genes in fetuses from $\mathrm{H}$ intake cows. These results indicate that these receptors could interact with GDF9 to stimulate the observed follicular growth, because GDF9 has its biologic effect by binding to TGFBR1 and BMPR2 on the membrane of target cells (Vitt et al., 2002; Mazerbourg et al., 2004). Collectively, these results corroborate the suggestion that the underlying mechanism of maternal overnutrition stimulus on fetal 
ovaries is the increased abundance of GDF9, BMPR2, and TGFBR1 that would lead to stimulate the folliculogenesis.

No changes in $E R \alpha$ expression levels were observed. However, the expression of the P450arom and StAR gene was higher in ovaries of fetuses from $\mathrm{H}$ than $\mathrm{M}$ intake cows. The enzyme StAR is a rate-limiting enzyme in steroidogenesis (Lin et al., 1995). The enzyme P450arom catalyzes the conversion of androgens to estrogens (Meinhardt and Mullis, 2002), and it is found in granulosa cells of primary, preantral, and antral follicles in fetal bovine ovaries at 190 DG (Burkhart et al., 2010). Upregulation of the P450arom and StAR genes could be the factor in the increment of primary, preantral, and antral follicle numbers in fetuses from $\mathrm{H}$ intake cows. This observation corroborate early studies that reported estrogens regulated early follicular growth (Britt et al., 2000; Drummond et al., 2002) and have a direct effect on the number and size of ovarian follicles (Nayudu and Osborn, 1992; Hulshof et al., 1995).

Maternal overnutrition did not affect testis weight probably because not all types of testicular tissue were affected equally, as demonstrated by quantitative histological analysis. Volumetric proportion as well as length and diameter of seminiferous cords were lower, but interstitium volumetric proportion was higher in the fetal testis from $\mathrm{H}$ intake cows. Although we did not measure pre-Sertoli cell numbers, the lower seminiferous cords measurement could be related to lower numbers of pre-Sertoli cells, because in fetal testis the seminiferous cords contain only pre-Sertoli cells and 1 or 2 pre-spermatogonias (Orth, 1993). Sertoli cells proliferate before and after birth coordinating testicular development in primates (Plant and Marshall, 2001). Their numbers are highly correlated with adult testicular size and sperm production, and alterations of their development directly affect other testicular cells such as Leydig and fetal germ cells, leading to disorders in human adulthood (Sharpe et al., 2003).

The IGF-1 plays a major role in the proper development and function of the testis (Baker et al., 1996; Froment et al., 2004; Griffeth et al., 2014), and it is produced by Leydig, Sertoli, and germ cells; and IGF1R is found in the germ cells and somatic testicular cells in human and rats (Vannelli et al., 1988; Cailleau et al., 1990). Pitetti et al. (2013) reported that inactivation of IGF1R in mouse pre-Sertoli cells reduced its proliferation during late gestation, which resulted in $79 \%$ reduction in daily sperm production in adulthood. Our results suggest that lower expression of $I G F 1$, $I G F 2$, and IGF1R receptor genes in fetal testis from $\mathrm{H}$ intake cows could explain detrimental changes in testicular structure. Less seminiferous cord tissue could mean lower proliferation of pre-spermatogonia and pre-
Sertoli cells, consistent with earlier studies in rats that reported IGF1 and IGF2 as regulators of germ cell proliferation and survival/maturation of Sertoli and Leydig cells during testis development (Söder et al., 1992; Pitetti et al., 2013). Moreover, according to Hochereaude Reviers et al. (1987), the diameter of seminiferous tubules in adults is highly correlated with the number of germ cells, so the smaller seminiferous cord diameter observed in our study may affect the number of germ and Sertoli cells per seminiferous tubule at postnatal age. Because each Sertoli cell has a fixed capacity for the number of germ cells that it can support (Orth et al., 1988), reduction of Sertoli cell numbers is likely to detrimentally affect offspring fertility. Upregulation of IGF may explain the increased expression of StAR and $H S D 17 B 3$ genes. In vitro, studies have demonstrated that IGF1 influenced the expression of key steroidogenic enzymes in the mouse testis during prenatal development (Villalpando and Lopez-Olmos, 2003).

\section{Effects of Days of Gestation on Fetal Growth, Pituitary Gland, and Gonadal Development}

As expected, fetal BW and reproductive organs measured increased in weight during progress of gestation; greater masses were observed at 268 DG for female fetuses and at 241 DG for male fetuses. The greater number of primary, preantral, and antral follicles with DG is consistent with Santos et al. (2013) that characterized folliculogenesis in bovine fetal ovary and revealed that as fetal age increased, primary and secondary follicles tended to increase in number. In male fetuses, the volumetric proportion of seminiferous cords decreased during gestation; the greater value was observed at 139 than 199 and 241 DG, whereas interstitium volumetric proportion increased with DG. Moreover, diameter and length of seminiferous cords were similar during gestational period evaluated, consistent with reported by Abd Elmaksoud (2005) that showed an increase in testicular differentiation and size during mid- and late-gestation in bovine fetuses.

We observed an increased in FSHB gene expression with DG in both sexes, consistent with a previous study in bovine fetuses demonstrating a gradual increase in pituitary content of FSH for both sexes with DG (Workewych and Cheng, 1979). Furthermore, the expression level of $L H B$ was increased with DG in male fetuses, but it was not differentially expressed in female fetuses. Our results differed from Workewych and Cheng (1979), who reported increase in pituitary content of LH for both sexes with DG.

The lower expression of $B a x$ and $C A S P 3$ genes in female fetuses at 268 DG compared with 199 DG, irrespective of maternal intake, is consistent with the 
tendency for the total number of follicles to decrease at 199 DG. These results are supported by Erickson (1966) and Santos et al. (2013), who reported waves of follicular degeneration occurring at this stage of gestation in the bovine fetal ovary. Moreover, the higher expression of StAR and P450arom genes at 268 than at 199 DG, irrespective of maternal intake, could be explained by greater number of follicles at late stage that are secreting estrogen. As the follicles grow and differentiate, the production of estrogen increases (Fortune, 1994).

The greater expression of IGF1, IGF2, and its receptor at 139 DG compared with 199 DG may reflect differences in the age of fetuses associated with stage of testicular development and also a stimulatory effect of these growth factors during testis development by increasing cell proliferation and differentiation, which in turn increased testicular size. Similarly, the greater expression of IGF1, IGF2, and IGF1R at 241 DG than at 199 DG observed in our study could reflect an increase in connective tissue related to fetal growth (Abd Elmaksoud, 2005). Despite IGF upregulation, StAR and $H S D 17 B 3$ expression was decreased at later stages of gestation and may reflect differences in steroidogenic capacity across stages of testicular development. In later stages of gestation, pre-Leydig cells are reduced due to regression or dedifferentiation to mesenchymal cells (Abd Elmaksoud, 2005).

\section{CONCLUSIONS}

This is the first study to demonstrate that maternal overnutrition during mid-late gestation might alter gonadal development and gene expression in cattle, for both male and female fetuses. Maternal overnutrition affected ovarian follicular growth and the number of follicles in female fetuses, which in turn may reduce their ovarian reserve and subsequent fertility. In male fetuses, testicular development was disturbed, which could have lasting effects on daily sperm production. The underlying mechanism seems to involve differential expression of multiple genes: $\mathrm{P} 450$ aromatase, StAR, BMPR2, TGFBR1, GDF9, FSHR, Bax, CASP3, HS$D 17 B 3, I G F 1, I G F 2$, and $I G F 1 R$. The functional meaning of the observed differential gene expression in terms of offspring reproductive potential should be the focus of further investigations, especially considering a larger sample size to reduce the chances of type I errors as the small sample size was a major limitation of this study.

\section{ACKNOWLEDGMENTS}

The authors gratefully acknowledge Conselho Nacional de Desenvolvimento Científico e Tecnológico (CNPq, Brazil), Fundação de Amparo à Pesquisa do
Estado de Minas Gerais (FAPEMIG, Brazil), Instituto Nacional de Ciência e Tecnologia de Ciência Animal (INCT-CA, Brazil), and Coordenação de Aperfeiçoamento de Pessoal de Nível Superior (CAPES, Brazil; Project PVE A125/2013) for their financial support.

\section{REFERENCES}

Abd-Elmaksoud, A. 2005. Morphological, glycohistochemical, and immunohistochemical studies on embryonic and adult bovine testis. DS Thesis. Ludwig-Maximilians Univ., Munich, Germany.

Aye, I. L., T. L. Powell, and T. Jansson. 2013. Review: AdiponectinThe missing link between maternal adiposity, placental transport and fetal growth? Placenta 34(Suppl.):S40-S45.

Baker, J., M. P. Hardy, J. Zhou, C. Bondy, F. Lupu, A. R. Bellvé, and A. Efstratiadis. 1996. Effects of an Igf1 gene null mutation on mouse reproduction. Mol. Endocrinol. 10:903-918. http://dx.doi. org $/ 10.1210 /$ mend.10.7.8813730.

Bao, B., H. A. Garverick, G. W. Smith, M. F. Smith, B. E. Salfen, and R. S. Youngquist. 1997. Changes in messenger RNA encoding LH receptor, cytochrome P450 side chain cleavage, and aromatase are associated with recruitment and selection of bovine ovarian follicles. Biol. Reprod. 56:1158-1168.

Bernal, A. B., M. H. Vickers, M. B. Hampton, R. A. Poynton, and D. M. Sloboba. 2010. Maternal undernutrition significantly impacts ovarian follicle number and increases ovarian oxidative stress in adult rat offspring. PloS ONE 5:e15558 http://dx.doi.org/10.1371/ journal.pone.0015558.

Bodensteiner, K. J., C. M. Clay, C. L. Moeller, and H. R. Sawyer. 1999. Molecular cloning of the ovine Growth/Differentiation factor-9 gene and expression of growth/differentiation factor-9 in ovine and bovine ovaries. Biol. Reprod. 60:381-386.

Britt, K. L., A. E. Drummond, V. A. Cox, M. Dyson, N. G. Wreford, M. E. Jones, E. R. Simpson, and J. K. Findlay. 2000. An agerelated ovarian phenotype in mice with targeted disruption of the Cyp 19 (aromatase) gene. Endocrinology 141:2614-2623. http:// dx.doi.org/10.1210/endo.141.7.7578.

Bruce, K. D., F. R. Cagampang, M. Argenton, J. Zhang, P. L. Ethirajan, G. C. Burdge, A. C. Bateman, G. F. Clough, L. Poston, M. A. Hanson, J. M. McConnell, and C. D. Byrne. 2009. Maternal highfat feeding primes steatohepatitis in adult mice offspring, involving mitochondrial dysfunction and altered lipogenesis gene expression. Hepatology 50:1796-1808.

Burkhart, M. N., J. L. Juengel, P. R. Smithb, D. A. Heathb, G. A Perry, M. F. Smith, and H. A. Garverick. 2010. Morphological development and characterization of aromatase and estrogen receptors alpha and beta in fetal ovaries of cattle from days 110 to 250. Anim. Reprod. Sci. 117:43-54. http://dx.doi.org/10.1016/j. anireprosci.2009.02.010.

Cailleau, J., S. Vermeire, and G. Verhoeven. 1990. Independent control of the production of insulin-like growth factor I and its binding protein by cultured testicular cells. Mol. Cell. Endocrinol. 69:7989.

Chadio, S., and B. Kotsampasi. 2014. The role of early life nutrition in programming of reproductive function. J. Dev. Orig. Health Dis. 5:2-15. http://dx.doi.org/10.1017/S204017441300038X.

Chavatte-Palmer, P., C. Dupont, N. Debus, and S. Camous. 2014. Nutritional programming and the reproductive function of the offspring. Anim. Prod. Sci. 54:1166-1176. http://dx.doi.org/10.1071/ AN14470.

Cheng, G., Z. Weihua, S. Makinen, S. Makela, S. Saji, M. Warner, J. A. Gustafsson, and O. Hovatta. 2002. A role for the androgen receptor in follicular atresia of estrogen receptor beta knockout mouse ovary. Biol. Reprod. 66:77-84. http://dx.doi.org/10.1095/ biolreprod66.1.77.

Connor, K. L., M. H. Vickers, J. Beltrand, M. J. Meaney, and D. M. Sloboda. 2012. Nature, nurture or nutrition? Impact of maternal nutrition on maternal care, offspring development and reproductive function. J. Physiol. 590:2167-2180. http://dx.doi. org/10.1113/jphysiol.2011.223305. 
Da Silva, P., R. P. Aitken, S. M. Rhind, P. A. Racey, and J. M. Wallace. 2003. Effect of maternal overnutrition during pregnancy on pituitary gonadotrophin gene expression and gonadal morphology in female and male foetal sheep at day 103 of gestation. Placenta $24: 248-257$.

Drummond, A. E., K. L. Britt, M. Dyson, M. E. Jones, J. B. Kerr, L. O'Donnell, E. R. Simpson, and J. K. Findlay. 2002. Ovarian steroid receptors and their role in ovarian function. Mol. Cell. Endocrinol. 191:27-33.

Erickson, D. H. 1966. Development and radio-response of the prenatal bovine ovary. J. Reprod. Fertil. 11:97-105.

Felici, M. D., A. D. Carlo, M. Pesce, S. Iona, M. G. Farrace, and M. Piacentini. 1999. Bcl-2 and Bax regulation of apoptosis in germ cells during prenatal oogenesis in the mouse embryo. Cell Death Differ. 6:908-915.

Fortune, J. E. 1994. Ovarian follicular growth and development in mammals. Biol. Reprod. 50:225-232. http://dx.doi.org/10.1095/ biolreprod50.2.225.

Froment, P., C. Staub, S. Hembert, C. Pisselet, M. Magistrini, B. Delaleu, D. Seurin, J. E. Levine, L. Johnson, M. Binoux, and P. Monget. 2004. Reproductive abnormalities in human insulin-like growth factor-binding protein-1 transgenic male mice. Endocrinology 145:2080-2091. http://dx.doi.org/10.1210/en.2003-0956.

Gougeon, A., and G. B. N. Chainy. 1987. Morphometric studies of small follicles in ovaries of women at different ages. J. Reprod. Fertil. 81:433-442.

Griffeth, R. J., V. Bianda, and S. Nerf. 2014. The emerging role of insulin-like growth factors in testis development and function. Basic. Clin. Androl. 24:12.

Guzmán, C., R. Garcia-Becerra, M. A. Aguilar-Medina, I. Mendez, H. Merchant-Larios, and E. Zambrano. 2014. Maternal protein restriction during pregnancy and/or lactation negatively affects follicular ovarian development and steroidogenesis in the prepubertal rat offspring. Arch. Med. Res. 45:294-300.

Harding, J. E., and B. M. Johnston. 1995. Nutrition and fetal growth. Reprod. Fertil. Dev. 7:539-547.

Hawkins, P., C. Steyn, T. Ozaki, T. Saito, D. E. Noakes, and M. A. Hanson. 2000. Effect of maternal undernutrition in early gestation on ovine fetal blood pressure and cardiovascular reflexes. Am. J. Physiol. Regul. Integr. Comp. Physiol. 279:R340-R348.

Hochereau-de Reviers, M. T., C. Monet-Kuntz, and M. Courot. 1987. Spermatogenesis and Sertoli cell numbers and function in rams and bulls. J. Reprod. Fertil. Suppl. 34:101-114.

Hulshof, S. C. J., J. R. Figueiredo, J. F. Beckers, M. M. Beyers, J. A. van der Donk, and R. Van Den Hurk. 1995. Effects of fetal bovine serum, FSH, and 17b-estradiol on the culture of bovine preantral follicles. Theriogenology 44:217-226. http://dx.doi. org/10.1016/0093-691X(95)00171-4.

Hussein, M. R. 2005. Apoptosis in the ovary: Molecular mechanisms. Hum. Reprod. Update 11:162-177. http://dx.doi.org/10.1093/ humupd/dmi001.

Ingelfinger, J. R., and A. M. Nuyt. 2012. Impact of fetal programming, birth weight, and infant feeding on later hypertension. J. Clin. Hypertens. (Greenwich) 14:365-371.

Jones, R. H., and S. E. Ozanne. 2009. Fetal programming of glucoseinsulin metabolism. Mol. Cell. Endocrinol. 297:4-9.

Kugu, K., V. S. Ratts, G. N. Piquette, K. I. Tilly, X. J. Tao, S. Martimbeau, G. W. Aberdeen, S. Krajewski, J. C. Reed, G. J. Pepe, E. D. Al-Brecht, and J. L. Tilly. 1998. Analysis of apoptosis and expression of bcl-2 gene family members in the human and baboon ovary. Cell Death Differ. 5:67-76.

Lea, R. G., L. P. Andrade, M. T. Rae, L. T. Hannah, C. E. Kyle, J. F. Murray, S. M. Rhind, and D. W. Miller. 2006. Effects of maternal undernutrition during early pregnancy on apoptosis regulators in the ovine fetal ovary. Reproduction 131:113-124. http://dx.doi. org/10.1530/rep.1.00844.

Léveillé, P., A. Tarrade, C. Dupont, T. Larcher, M. Dahirel, E. Poumerol, A. G. Cordier, O. Picone, B. Mandon-Pepin, G. Jolivet, R. Lévy, and P. Chavatte-Palmer. 2014. Maternal high fat diet induces follicular atresia but does not affect fertility in adult rabbit offspring. J. Dev. Orig. Health Dis. 5:88-97. http://dx.doi. org/10.1017/S2040174414000014

Lin, D., T. Sugawara, J. F. Strauss, B. J. Clark, D. M. Stocco, P. Saenger, A. Rogol, and W. L. Miller. 1995. Role of steroidogenic acute regulatory protein in adrenal and gonadal steroidogenesis. Science 267:1828-1831.

Livak, K. J., and T. D. Shmittgen. 2001. Analysis of relative expression data using real time quantitative $\mathrm{PCR}$ and the $2^{-\Delta \Delta \mathrm{Ct}}$ method. Methods 25:402-408.

Long, N. M., P. W. Nathanielsz, and S. P. Ford. 2012. The impact of maternal overnutrition and obesity on hypothalamic-pituitary-adrenal axis response of offspring to stress. Domest. Anim. Endocrinol. 42:195-202. http://dx.doi.org/10.1016/j.domaniend.2011.12.002.

Manly, B. F. J. 1997. Randomization, Bootstrap and Monte Carlo Methods in Biology. 2nd ed. Chapman \& Hall, London, UK.

Marshall, G. R., and T. M. Plant. 1996. Puberty occurring either spontaneously or induced precociously in rhesus monkey (Macaca mulatta) is associated with a marked proliferation of Sertoli cells. Biol. Reprod. 54:1192-1199.

Martins, F. S., J. J. Celestino, M. V. Saraiva, M. H. Matos, J. B. Bruno, C. M. Rocha-Junior, I. B. Lima-Verde, C. M. Lucci, S. N. Báo, and J. R. Figueiredo. 2008. Growth and differentiation factor-9 stimulates activation of goat primordial follicles in vitro and their progression to secondary follicles. Reprod. Fertil. Dev. 20:916-924. http://dx.doi.org/10.1071/RD08108.

Mazerbourg, S., C. Klein, J. Roh, N. Kaivo-Oja, D. G. Mottershead, O. Korchynskyi, O. Ritvos, and A. J. Hsueh. 2004. Growth differentiation factor-9 signaling is mediated by the type I receptor, activin receptor-like kinase 5. Mol. Endocrinol. 18:653-665.

Meinhardt, U., and P. E. Mullis. 2002. The essential role of the aromatase/p450arom. Semin. Reprod. Med. 20:277-284. http://dx.doi. org/10.1055/s-2002-35374.

Mossa, F., D. Kenny, F. Jimenez-Krassel, G. W. Smith, D. Berry, S. Butler, T. Fair, P. Lonergan, J. J. Ireland, and A. C. O. Evans. 2009. Undernutrition of heifers during the first trimester of pregnancy diminishes size of the ovarian reserve in female offspring. Page 77 in 42nd Annual Meeting of the Society for Study of Reproduction, Pittsburgh, PA.

Nandedkar, T. D., and S. J. Dharma. 2001. Expression of bcl(xs) and c-myc in atretic follicles of mouse ovary. Reprod. Biomed. Online $3: 221-225$.

Nayudu, P. L., and S. M. Osborn. 1992. Factors influencing the rate of preantral and antral growth of mouse ovarian follicles in vitro. J. Reprod. Fertil. 95:349-362. http://dx.doi.org/10.1530/ jrf.0.0950349.

Nilsson, E. E., and M. K. Skinner. 2002. Growth and differentiation factor-9 stimulates progression of early primary but not primordial rat ovarian follicle development. Biol. Reprod. 67:1018-1024. http://dx.doi.org/10.1095/biolreprod.101.002527.

Orth, J. M. 1993. Cell biology of testicular development in the fetus and neonate. Pages 3-42 in Cell and Molecular Biology of the Testis. C. Desjardins and L. L. Ewing, ed. Oxford University Press, Oxford, UK

Orth, J. M., G. L. Gunsalus, and A. A. Lamperti. 1988. Evidence from Sertoli cell-depleted rats indicates that spermatid number in adults depends on numbers of Sertoli cells produced during perinatal development. Endocrinology 122:787-794. http://dx.doi. org/10.1210/endo-122-3-787.

Paradis, F., S. Novak, G. K. Murdoch, M. K. Dyck, W. T. Dixon, and G. R. Foxcroft. 2009. Temporal regulation of BMP2, BMP6, BMP15, GDF9, BMPR1A, BMPR1B, BMPR2 and TGFBR1 mRNA expression in the oocyte, granulosa and theca cells of developing preovulatory follicles in the pig. Reproduction 138:115-129. http://dx.doi.org/10.1530/REP-08-0538.

Parlee, S. D., and O. A. Macdougald. 2014. Maternal nutrition and risk of obesity in offspring: The Trojan horse of developmental plasticity. Biochim. Biophys. Acta 1842:495-506. http://dx.doi. org/10.1016/j.bbadis.2013.07.007.

Piotrowska, H., B. Kempisty, P. Sosinska, S. Ciesiolka, D. Bukowska, P. Antosik, M. Rybska, K. P. Brussow, M. Nowicki, and M. Zabel. 
2013. The role of TGF superfamily gene expression in the regulation of folliculogenesis and oogenesis in mammals: A review. Vet. Med. 10:505-515.

Pitetti, J. L., P. Calvel, C. Zimmermann, B. Conne, M. D. Papaioannou, F. Aubry, C. R. Cederroth, F. Urner, B. Fumel, M. Crausaz, M. Docquier, P. L. Herrera, F. Pralong, M. Germond, F. Guillou, B. Jegou, and S. Nef. 2013. An essential role for insulin and IGF1 receptors in regulating Sertoli cell proliferation, testis size, and FSH action in mice. Mol. Endocrinol. 27:814-827. http://dx.doi. org $/ 10.1210 /$ me.2012-1258.

Plant, T. M., and G. R. Marshall. 2001. The functional significance of FSH in spermatogenesis and the control of its secretion in male primates. Endocr. Rev. 22:764-786.

Poljicanin, A., T. Vukusic-Pusic, K. Vukojevic, A. Caric, K. Vilovic, S. Tomic, V. Soljic, and M. Saraga-Babic. 2013. The expression patterns of pro-apoptotic and anti-apoptotic factors in human fetal and adult ovary. Acta Histochem. 115:533-540. http://dx.doi. org/10.1016/j.acthis.2012.11.009.

Portha, B., A. Chavey, and J. Movassat. 2011. Early-life origins of type 2 diabetes: Fetal programming of the beta-cell mass. Exp. Diabetes Res. 2011. http://dx.doi.org/10.1155/2011/105076.

Rae, M. T., S. Palassio, C. E. Kyle, A. N. Brooks, R. G. Lea, D. W. Miller, and S. M. Rhind. 2001. Maternal undernutrition during pregnancy retards early ovarian development and subsequent follicular development in fetal sheep. Reproduction 122:915-922. http://dx.doi.org/10.1530/rep.0.1220915.

Rae, M. T., S. M. Rhind, P. A. Fowler, D. W. Miller, and A. N Brooks. 2002. Effect of maternal undernutrition on fetal testicular steroidogenesis during the CNS androgen-responsive period in male sheep fetuses. Reproduction 124:33-39. http://dx.doi. org/10.1530/rep.0.1240033.

Rhind, S. M., M. T. Rae, and A. N. Brooks. 2001. Effects of nutrition and environmental factors on the fetal programming of the reproductive axis. Reproduction 122:205-214.

Richards, J. S. 1994. Hormonal control of gene expression in the ovary. Endocr. Rev. 15:725-751.

Rodríguez-González, G. L., C. C. Vega, L. Boeck, M. Vázquez, C. J. Bautista, L. A. Reyes-Castro, O. Saldaña, D. Lovera, P. W. Nathanielsz, and E. Zambrano. 2015. Maternal obesity and overnutrition increase oxidative stress in male rat offspring reproductive system and decrease fertility. Int. J. Obes. (Lond.) 39:549-556. http://dx.doi.org/10.1038/ijo.2014.209.

Rotta, P. P., S. C. Valadares Filho, T. R. Santos, L. F. Costa e Silva, T. E. Engle, M. I. Marcondes, F. S. Machado, F. A. C. Villadiego, and L. H. R. Silva. 2014. Effects of days of gestation and feeding regimen in Holstein $\times$ Gyr cows: I. Apparent total tract digestibility, nitrogen balance, microbial protein supply, and fat deposition. J. Dairy Sci. In press

Russell, L. D., H. P. Ren, I. Sinha Hikim, W. Schulze, and A. P. Sinha Hikim. 1990. A comparative study in twelve mammalian species of volume densities, volumes, and numerical densities of selected testis components, emphasizing those related to the Sertoli cell. Am. J. Anat. 188:21-30.

Santos, S. S. D., M. A. P. Ferreira, J. A. Pinto, R. V. Sampaio, A. C Carvalho, T. V. G. Silva, N. N. Costa, M. S. Cordeiro, M. S. Miranda, H. F. L. Ribeiro, and O. M. Oashi. 2013. Characterization of folliculogenesis and the occurrence of apoptosis in the development of bovine fetal ovary. Theriogenology 79:344-350. http:// dx.doi.org/10.1016/j.theriogenology.2012.09.026.

Schmatz, M., J. Madan, T. Marino, and J. Davis. 2010. Maternal obesity: The interplay between inflammation, mother and fetus. J. Perinatol. 30:441-446.

Seet, E. L., J. K. Yee, J. K. Jellyman, G. Han, M. G. Ross, and M. Desai. 2015. Maternal high-fat-diet programs rat offspring liver fatty acid metabolism. Lipids 50:565-573. http://dx.doi.org/10.1007/ s11745-015-4018-8.

Sharpe, R. M., C. McKinnell, C. Kivlin, and J. S. Fisher. 2003. Proliferation and functional maturation of Sertoli cells, and their relevance to disorders of testis function in adulthood. Reproduction $125: 769-784$
Sloboda, D. M., G. J. Howie, A. Pleasants, P. D. Gluckman, and M. H. Vickers. 2009. Pre- and postnatal nutritional histories influence reproductive maturation and ovarian function in the rat. PLoS ONE 4:e6744 http://dx.doi.org/10.1371/journal.pone.0006744.

Söder, O., P. Bang, A. Wahab, and M. Parvinen. 1992. Insulin-like growth factors selectively stimulate spermatogonial, but not meiotic, deoxyribonucleic acid synthesis during rat spermatogenesis. Endocrinology 131:2344-2350.

Steibel, J. P., R. Poletto, P. M. Coussens, and G. J. M. Rosa. 2009. A powerful and flexible linear mixed model framework for the analysis of relative quantification RT-PCR data. Genomics 94:146-152.

Sun, L. W., H. Y. Zhang, L. Wu, S. Shu, C. Xia, C. Xu, and J. S. Zheng. 2014. (1)H Nuclear magnetic resonance-based plasma metabolic profiling of dairy cows with clinical and subclinical ketosis. J. Dairy Sci. 97:1552-1562. http://dx.doi.org/10.3168/jds.20136757.

Symonds, M. E., and H. Budge. 2009. Nutritional models of developmental programming of adult health and disease. Proc. Nutr. Soc. 68:173-178. http://dx.doi.org/10.1017/S0029665109001049.

Tanaka, Y., K. Nakada, M. Moriyoshi, and Y. Sawamukai. 2001. Appearance and number of follicles and change in the concentration of serum FSH in female bovine foetuses. Reproduction 121:777-782.

Tenenbaum-Gavish, K., and M. Hod. 2013. Impact of maternal obesity on fetal health. Fetal Diagn. Ther. 34:1-7. http://dx.doi. org $/ 10.1159 / 000350170$

Tong, J. F., X. Yan, M. J. Zhu, S. P. Ford, P. W. Nathanielsz, and M. Du. 2009. Maternal obesity downregulates myogenesis and bcatenin signaling in fetal skeletal muscle. Am. J. Physiol. Endocrinol. Metab. 296:E917-E924.

Vandesompele, J., K. Preter, F. Pattyn, B. Poppe, N. Van Roy, A. De Paepe, and F. Speleman. 2002. Accurate normalization of realtime quantitative RT-PCR data by geometric averaging of multiple internal control genes. Genome Biol. 3:RESEARCH0034.

Vannelli, B. G., T. Barni, C. Orlando, A. Natali, M. Serio, and G. C. Balboni. 1988. Insulin-like growth factor-I (IGF-I) and IGF-I receptor in human testis: An immunohistochemical study. Fertil. Steril. 49:666-669.

Villalpando, I., and V. Lopez-Olmos. 2003. Insulin-like growth factor I (IGF-I) regulates endocrine activity of the embryonic testis in the mouse. J. Steroid Biochem. Mol. Biol. 86:151-158.

Vitt, U. A., S. Mazerbourg, C. Klein, and A. J. Hsueh. 2002. Bone morphogenetic protein receptor type II is a receptor for growth differentiation factor-9. Biol. Reprod. 67:473-480. http://dx.doi. org/10.1095/biolreprod67.2.473.

Vitt, U. A., E. A. McGee, M. Hayashi, and A. J. Hsueh. 2000. In vivo treatment with GDF-9 stimulates primordial and primary follicle progression and theca cell marker Cyp17 in ovaries of immature rats. Endocrinology 141:3814-3820.

Williams,, L., Y. Seki, P. M. Vuguin, and M. J. Charron. 2014. Animal models of in utero exposure to a high fat diet: A review. Biochim. Biophys. Acta 1842:507-519.

Workewych, J., and K. W. Cheng. 1979. Development of glycoprotein hormones and their alpha- and beta-subunits in bovine fetal pituitary glands. I. Quantitation of thyrotropin, follicle-stimulating hormone, and luteinizing hormone by radioligand receptor assays. Endocrinology 104:1069-1074.

Wrobel, K. H. 2000. Prespermatogenesis and spermatogoniogenesis in the bovine testis. Anat. Embryol. (Berl.) 202:209-222

Yoon, S. J., K. H. Choi, and K. A. Lee. 2002. Nitric oxide-mediated inhibition of follicular apoptosis is associated with HSP70 induction and Bax suppression. Mol. Reprod. Dev. 61:504-510.

Zambrano, E., C. Guzmán, G. L. Rodriguez-González, M. DurandCarbajal, and P. W. Nathanielsz. 2014. Fetal programming of sexual development and reproductive function. Mol. Cell. Endocrinol. 382:538-549. http://dx.doi.org/10.1016/j.mce.2013.09.008.

Zhang, L., N. M. Long, S. M. Hein, Y. Ma, P. W. Nathanielsz, and S. P. Ford. 2011. Maternal obesity in ewes results in reduced fetal pancreatic $\beta$-cell numbers in late gestation and decreased circulating insulin concentration at term. Domest. Anim. Endocrinol. 40:30-39. http://dx.doi.org/10.1016/j.domaniend.2010.08.004. 